\title{
Systemic Propagation of a Fluorescent Infectious Clone of a Polerovirus Following Inoculation by Agrobacteria and Aphids
}

\author{
Sylvaine Boissinot ${ }^{1}$, Elodie Pichon ${ }^{1,2}$, Céline Sorin ${ }^{3,4}$, Céline Piccini ${ }^{3}$, Danièle Scheidecker ${ }^{3}$, \\ Véronique Ziegler-Graff ${ }^{3}$ and Véronique Brault ${ }^{1, *}$ \\ 1 Université de Strasbourg, Institut National de la Recherche Agronomique, SVQV UMR-A 1131, \\ 68000 Colmar, France; sylvaine.boissinot@inra.fr (S.B.); elodie.pichon@inra.fr (E.P.) \\ 2 UMR 385 BGPI, Institut National de la Recherche Agronomique-Centre de Coopération Internationale en \\ Recherche Agronomique pour le Développement, SupAgro, CIRAD TA-A54/K, Campus International de \\ Baillarguet, 34398 Montpellier, France \\ 3 Institut de Biologie Moléculaire des Plantes, Centre National de la Recherche Scientifique, UPR 2357, \\ Université de Strasbourg, 12 rue du Général Zimmer, 67084 Strasbourg, France; \\ celine.sorin@ips2.universite-paris-saclay.fr (C.S.); celine.piccini@hotmail.com (C.P.); \\ daniele.scheidecker@ibmp-cnrs.unistra.fr (D.S.); veronique.ziegler-graff@ibmp-cnrs.unistra.fr (V.Z.-G.) \\ 4 Institute of Plant Science Paris Saclay (IPS2), CNRS, INRA, University Paris Diderot, \\ University of Paris-Saclay, 91405 Orsay, France \\ * Correspondence: veronique.brault@inra.fr; Tel.: +33-(0)389-224-934
}

Academic Editor: K. Andrew White

Received: 3 May 2017; Accepted: 22 June 2017; Published: 29 June 2017

\begin{abstract}
A fluorescent viral clone of the polerovirus Turnip yellows virus (TuYV) was engineered by introducing the Enhanced Green Fluorescent Protein (EGFP) sequence into the non-structural domain sequence of the readthrough protein, a minor capsid protein. The resulting recombinant virus, referred to as TuYV-RT $\mathrm{GFP}$, was infectious in several plant species when delivered by agroinoculation and invaded efficiently non-inoculated leaves. As expected for poleroviruses, which infect only phloem cells, the fluorescence emitted by TuYV-RT $\mathrm{GFP}_{\text {was }}$ restricted to the vasculature of infected

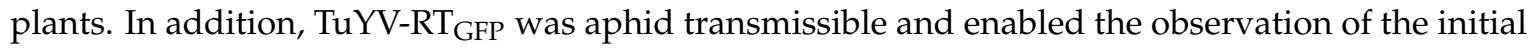
sites of infection in the phloem after aphid probing in epidermal cells. The aphid-transmitted virus moved efficiently to leaves distant from the inoculation sites and importantly retained the EGFP sequence in the viral genome. This work reports on the first engineered member in the Luteoviridae family that can be visualized by fluorescence emission in systemic leaves of different plant species after agroinoculation or aphid transmission.
\end{abstract}

Keywords: polerovirus; fluorescent clone; systemic infection; aphid transmission

\section{Introduction}

Turnip yellows virus (TuYV, formerly BWYV-FL1) is a member of the Polerovirus genus in the Luteoviridae family. Its single-stranded positive sense RNA genome of approximately $6 \mathrm{~kb}$ is encapsidated into isometric particles of $25 \mathrm{~nm}$ in diameter. TuYV has a wide host range among herbaceous plants and infects important crops such as oilseed rape [1]. The genome consists of seven interlocked and overlapping open reading frames (ORFs), which are expressed from the genomic and subgenomic RNAs by non-canonical translation mechanisms [2]. Members of the Luteoviridae are strictly restricted to the three cell types constituting the phloem; the nucleated phloem parenchyma cells and companion cells, where the virus replicates, and the sieve elements, which convey the virus to sites distant from the inoculation point [3-6]. TuYV is obligatorily transmitted by aphids in a circulative 
and non-propagative mode [7]. The virus, acquired by the aphid while ingesting phloem sap from an infected plant, is transported successively through the intestinal epithelium and the accessory salivary gland cells before being released into a plant along with the saliva [8].

Using site-directed mutagenesis on a full-length TuYV infectious clone, specific roles have been attributed to the different virus-encoded proteins; P0 is the viral silencing suppressor that counteracts the plant defense pathway by degrading ARGONAUTE1 a key enzyme of the RNA silencing machinery [9-13]. P1 and P2 contain domains corresponding to a serine protease, the viral genome-linked protein (VPg), a helicase, and the polymerase [14,15]. The proteins encoded by the ORFs located at the $3^{\prime}$ end of the genome are expressed from a subgenomic RNA. ORF3 encodes the major coat protein (CP) and ORF5 the readthrough domain (RTD), which is expressed by a readthrough mechanism of the CP stop codon. This process results in the synthesis of a fusion protein, referred to as the readthrough protein (RT), containing the $\mathrm{CP}$ in its $\mathrm{N}$-terminal part and the RTD in its C-terminus. A C-terminally truncated form of the RT, named $\mathrm{RT}^{*}$, is present as a minor component in the virus particle [16-18]. Poleroviruses CP and RT are involved in virus movement, and the RT* is strictly required for aphid transmission [5,17,19-25]. ORF4, embedded in ORF3, encodes a host-specific movement protein [26-29]. Very recently, a short ORF expressed from a non-canonical initiation codon and referred to as ORF3a was identified by in silico analyses. The encoded protein of about $5 \mathrm{kDa}$ was shown to be essential for TuYV long-distance movement [2].

Up to now, TuYV localization in infected plants was only achieved by observing whole virions by transmission electron microscopy or by detecting the major structural protein by in situ immunolocalization using specific antibodies [3-5]. Although these techniques are informative and contributed to deciphering the role of the RT protein in TuYV movement, they are laborious and time consuming. Moreover, these destructive methods limit the monitoring of the virus progression kinetics after inoculation. In order to gain a better understanding of polerovirus movement in plants, we engineered an Enhanced Green Fluorescent Protein EGFP-tagged full-length infectious clone of TuYV. Only two Green Fluorescent Protein (GFP)-labelled poleroviruses have been reported so far, but none of them were able to stably infect systemically the inoculated plants [30,31]. The difficulty in obtaining a fluorescently-tagged polerovirus resides in the introduction of extra sequences into the dense genome containing several overlapping ORFs, without altering virus infectivity. Using former and recent data on the viral sequences required for the readthrough mechanism of the CP stop codon, for the encapsidation of the $\mathrm{RT}^{*}$ into the viral particles and for virus efficient movement in plants, we designed a TuYV fluorescent clone by replacing the C-terminal part of the RT protein with the EGFP sequence. When delivered by agroinoculation or by aphids, TuYV-RT GFP $_{\text {was }}$ able to invade the non-inoculated leaves of host species belonging to three plant families. As expected for a

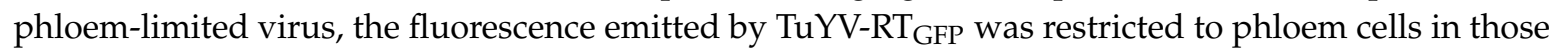
hosts. Interestingly, the initial phloem infection sites following aphid probing in epidermal cells were also observed. This represents the first report of a tagged virus in the Luteoviridae family that is able to develop a systemic infection after delivery by aphids or agroinfiltration.

\section{Materials and Methods}

\subsection{TuYV Constructs}

TuYV-RT ${ }_{\text {GFP }}$ was constructed by replacing the NcoI-SalI fragment corresponding to the 3' end of the TuYV sequence (nt 4822-downstream of the viral sequence) with a modified fragment containing the EGFP sequence [32] flanked by viral sequences. This fragment was built by regular restriction-ligation cloning of three PCR fragments into pBluescript KS plasmid (Stratagene). A first PCR fragment corresponding to the viral sequence 4822-4946 flanked by an NcoI site and a BamHI site was introduced into pKS digested with $\mathrm{NcoI}$ and BamHI enzymes. A second PCR fragment corresponding to the viral sequence 5469-5641 flanked by EcoRI sites and SalI sites, respectively, was inserted in the corresponding sites of the former vector. Finally, the EGFP sequence flanked by BamHI and EcoRI sites was introduced 
between the two former fragments in the recombinant pKS plasmid. The resulting NcoI-SalI fragment was excised and used to replace the corresponding fragment in the pBW. A- vector [33], generating

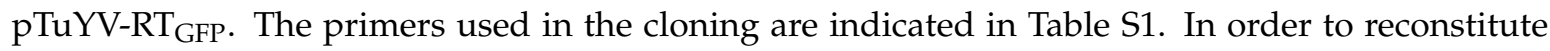
the agroinfection binary vector pbinTuYV-RT $\mathrm{GFP}$ containing full-length TuYV cDNA with the EGFP

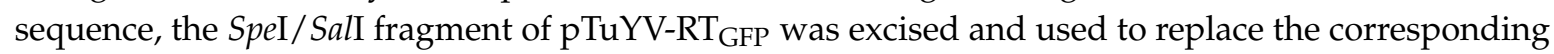
sequence of pbinTuYV-WT. All constructs were verified by sequencing.

\subsection{Protoplasts and Plant Infection}

Chenopodium quinoa protoplasts were prepared and inoculated as described by Ziegler-Graff et al. [29].

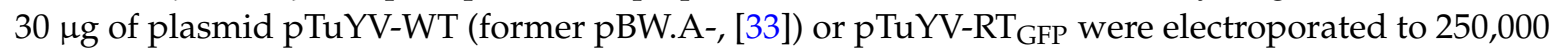
protoplasts using a pulse of $200 \mathrm{~V}$. The protoplasts were harvested $48 \mathrm{~h}$ post-inoculation, and the RNA and proteins contents were analyzed.

The plants were either inoculated by agrobacteria or by viruliferous aphids. For agroinoculation, pbin plasmids containing the viral sequences were introduced into Agrobacterium tumefaciens $\mathrm{C} 58 \mathrm{C} 1$ [34], and a cell culture was grown to an $\mathrm{OD}_{600}$ of 0.5 before being agroinfiltrated into three to five week old Arabidopsis thaliana, Montia perfoliata, or Nicotiana benthamiana [35]. For virus inoculation by aphids, virus suspensions were purified from $M$. perfoliata agroinoculated leaves, following the procedure described by van den Heuvel et al. [36]. Purified virus particles were observed by immunosorbent electron microscopy as described previously [37]. After a $24 \mathrm{~h}$ acquisition period on an artificial medium containing $100 \mathrm{ng} / \mu \mathrm{L}$ of virus in MP148 [22], 10 Myzus persicae (Sulzer) were transferred onto M. perfoliata or A. thaliana for virus inoculation. Alternately, 30 M. persicae ssp. nicotianae were transferred onto $N$. benthamiana. Four days after inoculation, the aphids were eliminated with Pirimor (Guyancourt, France) insecticide $(0.5 \mathrm{mg} / \mathrm{mL})$. When the aphid-inoculated leaves were used for microscopic observations, the aphids were fed on purified virus at a concentration set up to $300 \mathrm{ng} / \mu \mathrm{L}$ before being enclosed in clip-cages (10 aphids per clip-cage) deposited on M. perfoliata. The aphids were then removed with a brush before observations.

\subsection{Detection of Viral RNA and Capsid Proteins}

Total RNAs were extracted from protoplasts as described by Veidt et al. [38]. Viral RNA was detected by Northern blot using a ${ }^{32} \mathrm{P}$-dCTP labelled PCR probe complementary to a domain common to TuYV-WT and TuYV-RT GFP (nt 4411-4827). RNA loading was controlled by staining the membrane using methylene blue. RNA quantification on Northern blots was performed using ImageGauge software (Fujifilm, Saint-Quentin-en-Yvelines, France) and the ImageJ processing program (https:/ /imagej.nih.gov, Rockville Pike, MD, USA). The presence of the EGFP sequence in the viral progeny of the infected plants was analysed following the extraction of total RNA from the plant tissue using a commercial RNA purification kit (NucleospinRNA plant, Macherey Nagel). RNA was then subjected to reverse transcription (M-MLV reverse transcriptase; Promega), with the reverse primer (RP) complementary to the 3'-untranslated region of TuYV (Table S1). PCR-amplified fragments were obtained using the primer RP and the forward primer FP (Table S1) in the ORF5 sequence of TuYV viruses.

Viral proteins were detected in protoplasts or in agroinfiltrated N. benthamiana leaves by western blot using a polyclonal antisera raised against the TuYV-CP protein [22] and in non-inoculated leaves by double-antibody sandwich enzyme-linked immunosorbent assay (DAS-ELISA) with a TuYV-specific polyclonal antiserum (Loewe) [39]. Alternately, a homemade antiserum raised against the GFP protein was used. Briefly, protoplasts were directly disrupted using Laemmli buffer [40], and plant proteins were first ground with glass beads in liquid nitrogen before being denatured using Laemmli buffer and centrifuged for $5 \mathrm{~min}$ at 10,000 rpm. Proteins separated on a 10\% or $11 \%$ sodium dodecyl sulfate polyacrylamide gel electrophoresis (SDS-PAGE) were transferred on a polyvinylidene difluoride (PVDF) Immobilon-P membrane (Merck-Millipore, Molsheim, France) and further incubated with primary antibodies (mentioned above). After the addition of a secondary antibody (goat-anti 
rabbit-HRP conjugate, Invitrogen, Camrillo, CA, USA) and HRP substrate (Lumi-LightPLUS kit, Roche, Mannheim, Germany) the protein/antibody complex was detected with a cooled high sensitive camera (Gbox, Syngene, Cambridge, United Kingdom) or by autoradiography. For loading controls, the nitrocellulose membranes were stained with Ponceau Red.

\subsection{Epifluorescence Microscopy}

Hand-cut cross and longitudinal sections of stems and petioles were mounted in water. To observe A. thaliana veins, the upper side of the leaf was stuck on a tape and the epidermal and mesophyll cells of the other face were removed with a second tape, thus releasing the vascular tissue. The vein network was then collected with tweezers and mounted in water. GFP fluorescence was observed using an Axio Imager M2 microscope (Zeiss, Marly le Roi, France) equipped with a Hamamatsu digital camera. Observations were performed on non-inoculated leaves of N. benthamiana, A. thaliana, and M. perfoliata two to three weeks post-infection, on inoculated leaves of $N$. benthamiana after agroinfiltration, or on M. perfoliata after virus inoculation by aphids. Some of the observations are optical sections obtained using structured illumination (ApoTome, Zeiss). For macroscopic observations, the leaves were observed on whole plants with an epifluorescence macroscope (Axiozoom.V16, Zeiss) equipped with a colour camera (Axiocam 506 color, Zeiss).

\section{Results}

\subsection{Infectivity of TuYV-RT $T_{G F P}$ in Protoplasts and Inoculated Leaves}

In order to obtain a fluorescent TuYV virus, the sequence of the enhanced GFP [32] was introduced into the ORF5, encoding the RTD by replacing the C-terminal part of the RTD in the full-length TuYV infectious clone [33]. The RTD domain is involved in virus movement, although not strictly mandatory, but is essential for aphid transmission $[17,22,25]$. The resulting virus was named TuYV-RT $\mathrm{GFP}_{\text {. }}$ The EGFP sequence was positioned 51 amino acids downstream of the lysine 437, the last amino acid of the RT* identified by mass spectrometry [41] (Figure 1). The required sequences for the readthrough mechanism of the $\mathrm{CP}$ stop codon [22] were maintained in the engineered virus. Due to the cloning strategy, $\mathrm{TuYV}_{\mathrm{Y}} \mathrm{RT}_{\mathrm{GFP}}$ retained plasmid derived-sequences that introduced non-viral amino acids at the flanking extremities of the EGFP (five and two extra amino acids at the $\mathrm{N}$ - and $\mathrm{C}$-terminus of the EGFP, respectively) (Figure 1). In addition, the last eight amino acids of the RT protein were conserved downstream of the C-terminal extremity of the EGFP. 


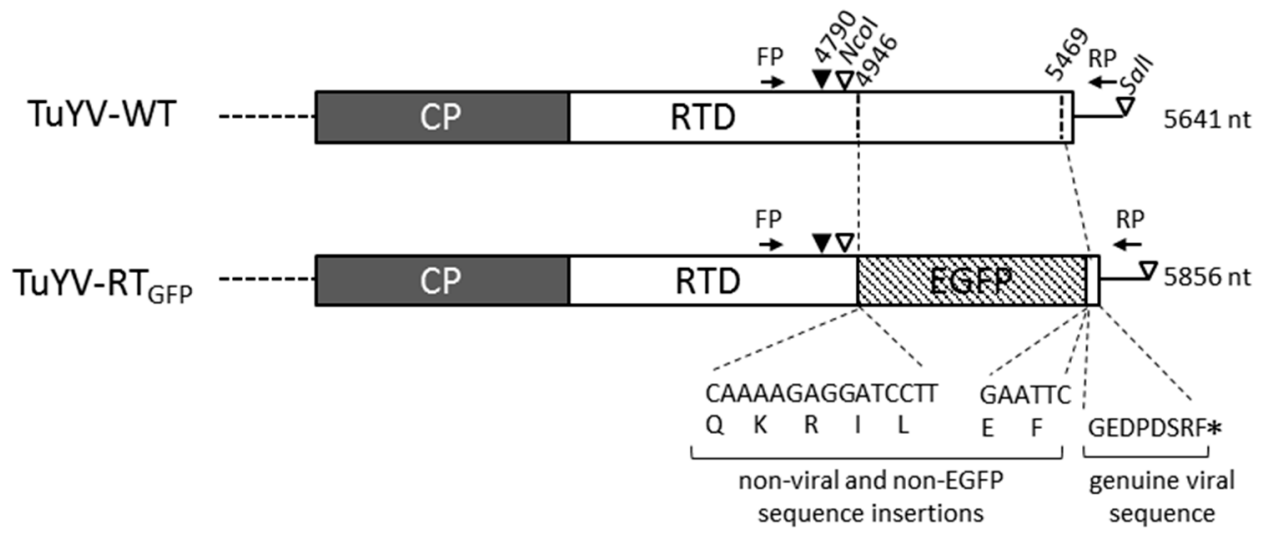

Figure 1. Schematic representation of the coat protein (CP) and the readthrough domain (RTD)-encoded open reading frame (ORF) at the $3^{\prime}$ of the wild-type polerovirus Turnip yellows virus (TuYV) TuYV-WT

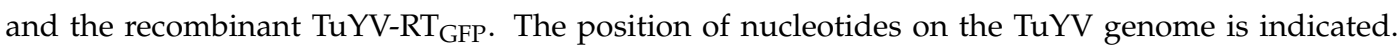
Extra non-viral and non-EGFP (enhanced green fluorescent protein) nucleotides introduced in the TuYV-RT $\mathrm{GFP}_{\mathrm{GF}}$ genome and the corresponding amino acids are shown together with the viral-encoded eight amino acids at the C-terminal end of the fusion protein. The positions of the forward and reverse

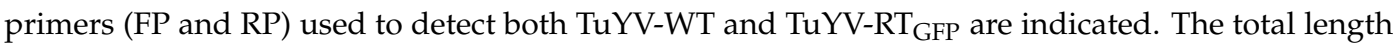
of each virus genome is reported. $\mathbf{v}$ : position of $\mathrm{K} 437$ (nt 4790), the last amino acid identified in the truncated readthrough (RT) protein; $\nabla$ : position of the NcoI and SalI sites used in the cloning procedure; *: ORF5 stop codon.

The infectivity of TuYV-RT $\mathrm{GFP}_{\text {was }}$ first addressed following the inoculation of Chenopodium quinoa protoplasts with the DNA construct containing the TuYV-RT ${ }_{\mathrm{GFP}}$ genome under the control of the Cauliflower mosaic virus $35 \mathrm{~S}$ promoter. Forty-eight hours after inoculation, both genomic and

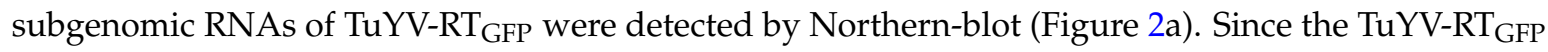
genome was $215 \mathrm{nt}$ longer than the wild-type genome (TuYV-WT), both RNA species migrated more slowly than the wild-type genomic and subgenomic RNAs. A reduction of TuYV-RT $\mathrm{GFP}_{\text {genomic }}$ and subgenomic RNAs accumulation ranging from 40 to $60 \%$ was observed compared with the TuYV-WT RNAs, suggesting that the introduction of the EGFP sequence into the TuYV genome slightly impaired virus replication in C. quinoa protoplasts (Figure 2a and data not shown). The detection of CP and RT-derived products was performed by western blot on the same C. quinoa protoplasts. Antibodies directed against the $\mathrm{CP}$ allowed The detection of the $\mathrm{CP}$ of $22 \mathrm{kDa}$ and the RT protein fused

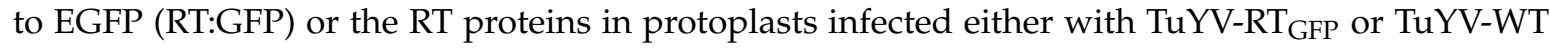
(Figure 2b, left panel). Indeed, both RT:GFP and RT proteins contain the $\mathrm{CP}$ at their $\mathrm{N}$-terminus. $\mathrm{CP}$ and RT:GFP accumulations in the extract of protoplasts infected with TuYV-RT $\mathrm{GFP}_{\mathrm{GP}}$ were slightly reduced compared to the wild-type virus, confirming the lower accumulation of the viral RNAs observed by Northern-blot (Figure 2a). The RT:GFP protein was also detected in the same extracts by antibodies directed against the GFP, confirming the hybrid nature of the protein (Figure 2b, right panel). Due to its larger size (76 kDa theoretical molecular weight), the RT:GFP migrated more slowly than the wild-type RT (74 kDa theoretical molecular weight), while both proteins displayed higher apparent molecular weights (around 97 and $95 \mathrm{kDa}$ respectively) as already reported before for the RT protein [17,22]. Due to the presence of a non-specific signal around $30 \mathrm{kDa}$ when using the anti-GFP serum, which could mask a potential release of the EGFP from the RT:GFP, the cleavage of the fusion protein in protoplasts could not be addressed with confidence. However, the equal intensity of the signal at $30 \mathrm{kDa}$ in all

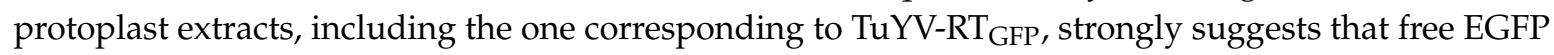
is not efficiently released from the RT:GFP (Figure $2 b$, right panel). 


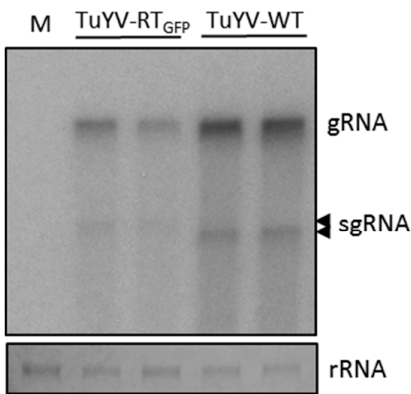

(a)

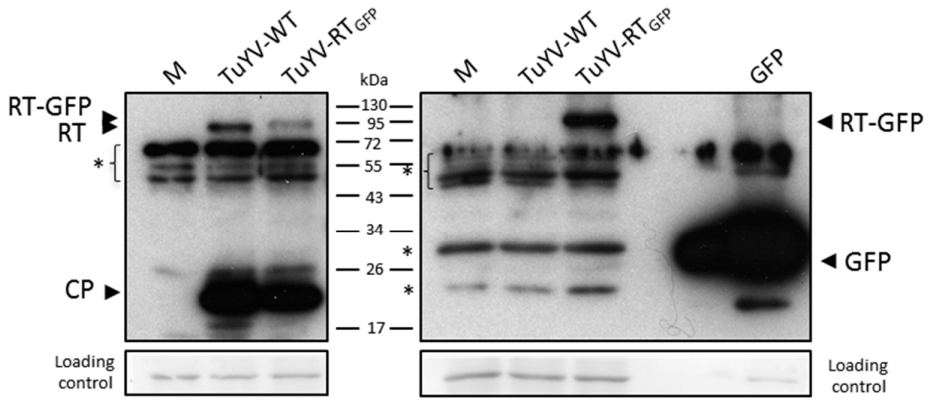

(b)

Figure 2. Viral replication and protein synthesis by TuYV-RT $\mathrm{GFP}_{\mathrm{G}}$ in Chenopodium quinoa protoplasts. (a) Northern-blot analysis of total RNA extracted from 120,000 protoplasts inoculated with DNA constructs corresponding to TuYV-RT $\mathrm{GFP}_{\mathrm{G}}$ or TuYV-WT, $48 \mathrm{~h}$ after inoculation. (M): mock-inoculated protoplasts. The position of the genomic (gRNA) and subgenomic (sgRNA) RNAs is indicated on the right. The loading control corresponds to methylene blue stained rRNAs; (b) Western blot analysis

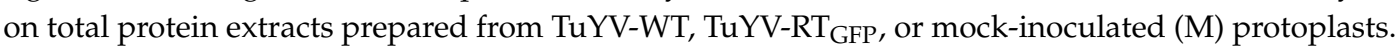
As a control, proteins from Nicotiana benthamiana were infiltrated with agrobacteria containing a binary plasmid with the enhanced green fluorescent protein sequence (GFP). Two acrylamide gels were loaded in parallel with similar protoplast protein extracts and further transferred onto PVDF membranes. One membrane was incubated with antibodies raised against the TuYV coat protein $(\mathrm{CP})$ revealing both $\mathrm{CP}$ and the readthrough protein (RT) (left panel) and the other was incubated with an antiserum directed against the GFP (right panel). *: non-specific products; Positions of the molecular markers (in $\mathrm{kDa}$ ) are indicated. Ponceau red stained proteins serve as the loading control.

To further analyze the infectivity of TuYV-RT $\mathrm{GFP}_{\text {in }}$ whole leaves, the former TuYV-RT $\mathrm{GFP}_{\text {construct }}$ was introduced into a binary vector and inoculated into several plant species via Agrobacterium tumefaciens. The virus accumulation was evaluated by double antibody sandwich-ELISA and, as shown in Table 1, TuYV-RT GFP accumulated in the agroinfiltrated leaves of Nicotiana benthamiana, Montia perfoliata, and Arabidopsis thaliana at a level close to TuYV-WT. Immunodetection performed on whole protein extracts showed the presence of both CP and RT:GFP proteins in the agroinfiltrated leaves of $N$. benthamiana (Figure S1). No cleavage product of the RT:GFP was observed.

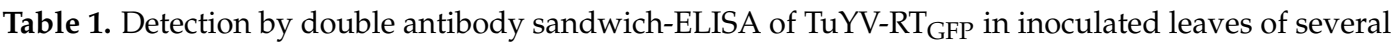
plant species.

\begin{tabular}{|c|c|c|c|c|c|c|}
\hline & \multicolumn{2}{|c|}{ Nicotiana benthamiana } & \multicolumn{2}{|c|}{ Montia perfoliata } & \multicolumn{2}{|c|}{ Arabidopsis thaliana } \\
\hline & $\begin{array}{l}\mathrm{Nb} \text { pl. inf. } / \mathrm{pl} \text {. } \\
\text { inoc. }{ }^{1}\end{array}$ & $\mathrm{OD} \pm \mathrm{SD}^{2}$ & $\begin{array}{l}\mathrm{Nb} \text { pl. inf./pl. } \\
\text { inoc. }{ }^{1}\end{array}$ & $\mathrm{OD} \pm \mathrm{SD}^{2}$ & $\begin{array}{l}\mathrm{Nb} \text { pl. inf./pl. } \\
\text { inoc. }{ }^{1}\end{array}$ & $\mathrm{OD} \pm \mathrm{SD}^{2}$ \\
\hline TuYV-RT $_{\text {GFP }}$ & $4 / 4$ & $2.59 \pm 0.42$ & $3 / 3$ & $2.11 \pm 0.15$ & $4 / 4$ & $1.80 \pm 0.87$ \\
\hline TuYV-WT & $3 / 3$ & $2.87 \pm 0.05$ & $4 / 4$ & $2.61 \pm 0.20$ & $4 / 4$ & $1.83 \pm 0.59$ \\
\hline pbin-Ø & $0 / 2$ & $0.16 \pm 0.00$ & $0 / 2$ & $0.14 \pm 0.01$ & $0 / 2$ & $0.11 \pm 0.01$ \\
\hline Non-inoc. ${ }^{3}$ & $0 / 2$ & $0.15 \pm 0.01$ & $0 / 2$ & $0.14 \pm 0.00$ & $0 / 1$ & $0.10 \pm 0.00$ \\
\hline
\end{tabular}

${ }^{1}$ Number of plants infected/plants inoculated. A plant is considered infected when the optical density (OD) value of the leaf extract is above the mean OD values of three non-infected plants and three times the standard deviation of these values. ${ }^{2}$ The mean absorbance value at $405 \mathrm{~nm}$ of the agroinfiltrated leaves four to seven days after inoculation \pm Standard Deviation. ${ }^{3}$ Non-inoculated plants. pbin-Ø: empty binary vector.

In both assays (protoplasts and plants), western blot and/or DAS-ELISA analysis allowed the detection of the CP and RT proteins expressed from the sub-genomic RNA, confirming genuine virus replication since direct translation from the $35 \mathrm{~S}$ promoter-derived transcripts could not result in the synthesis of both proteins. Taken together, these results showed that TuYV-RTGFP was replication-competent in several host species and produced the expected RT:GFP fusion protein. 


\subsection{Viral Particle Formation}

The formation of TuYV particles is a pre-requisite for virus systemic movement [42]. In order to address the ability of TuYV-RT $\mathrm{GFP}_{\mathrm{GP}}$ to produce virus particles, virions were purified from M. perfoliata

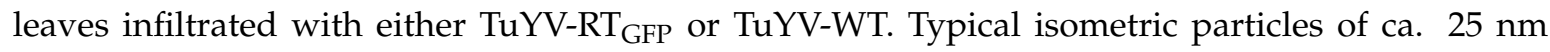

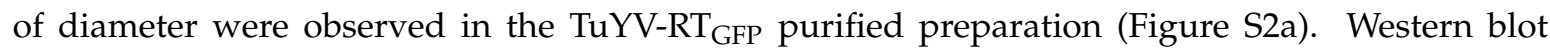

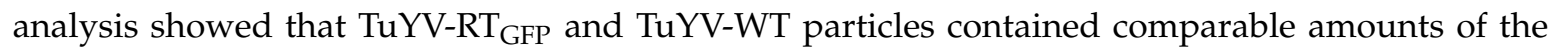
truncated RT protein $\left(\mathrm{RT}^{*}\right)$, suggesting that the EGFP inserted in the RT:GFP protein did not affect the processing of the fusion protein nor the incorporation of the $\mathrm{RT}^{*}$ into virus particles (Figure S2b). When the blot was incubated with an antiserum directed against GFP, no signal was detected in the

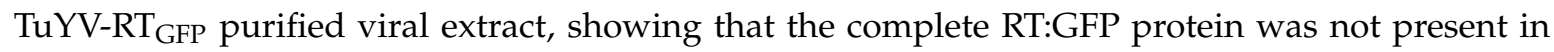
virions (data not shown). Together these results show that the protein compositions of TuYV-WT and

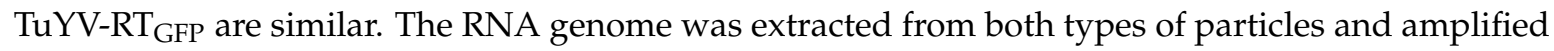
by reverse transcription-polymerase chain reaction (RT-PCR) using primers hybridizing within the TuYV 3' noncoding sequence and within a central sequence of the RTD (primers FP and RP, Figure 1). The presence of a unique RT-PCR fragment of the expected size in the TuYV-RT ${ }_{\mathrm{GFP}}$ virus extract (1085 $\mathrm{bp}$ ) indicates that the viral genome has conserved the entire EGFP sequence while a DNA fragment of $870 \mathrm{bp}$ is produced for TuYV-WT (Figure S2c).

\subsection{Systemic Movement of TuYV-RT $G F P$}

The capacity of TuYV-RT $\mathrm{GFP}_{\text {to }}$ to traffic to non-inoculated leaves was addressed by agroinoculating young plants of three different species with the TuYV-RT $\mathrm{GFP}_{\mathrm{GF}}$ binary construct. The presence of the virus

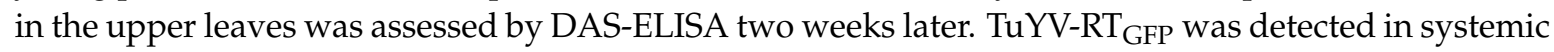
leaves of $N$. benthamiana, M. perfoliata, and A. thaliana, but the percentage of infected plants differed depending on the plant species. The ability of TuYV-RT $\mathrm{GFP}_{\text {to }}$ to reach systemic leaves in N. benthamiana was slightly reduced compared to TuYV-WT (50 to $76 \%$ of infected plants for TuYV-RT $\mathrm{GFP}_{\text {and }} 86$ to $100 \%$ for TuYV-WT) while the infection rate of TuYV-RT $\mathrm{GFP}_{\mathrm{G}}$ in $M$. perfoliata was closed to the wild-type virus (mean of $71 \%$ of infected plants for TuYV-RT $\mathrm{GFP}_{\text {and }} 77.5 \%$ for TuYV-WT) (Table 2). In contrast,

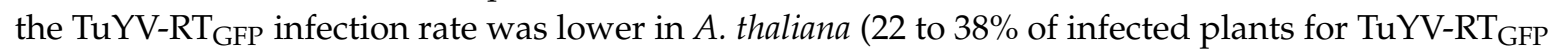

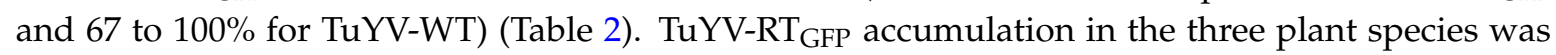
always lower when compared to the wild-type virus accumulation, but, due to important variability in the DAS-ELISA values between plants, a statistical analysis could not be performed. In contrast to TuYV-WT, which induces a moderate leaf chlorosis on N. benthamiana or reddening symptoms on old leaves of M. perfoliata, no symptoms were observed on plants infected with TuYV-RT $\mathrm{GFP}_{\text {. These }}$ results reinforce the hypothesis that the C-terminal part of the RT protein of TuYV is involved in symptom development [22]. A. thaliana, on the other hand, remained symptomless when infected with

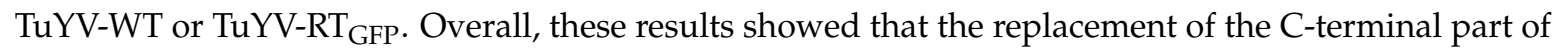

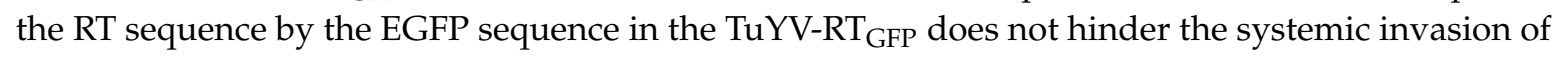
non-inoculated leaves. 
Table 2. Detection by double antibody sandwich (DAS)-ELISA of TuYV-RT $\mathrm{GFP}_{\text {in }}$ the non-inoculated leaves of three plant species.

\begin{tabular}{|c|c|c|c|c|c|c|c|c|c|c|c|c|c|c|}
\hline & \multicolumn{6}{|c|}{ Nicotiana benthamiana } & \multicolumn{4}{|c|}{ Montia perfoliata } & \multicolumn{4}{|c|}{ Arabidopsis thaliana } \\
\hline & \multicolumn{2}{|c|}{ Exp.1 } & \multicolumn{2}{|c|}{ Exp.2 } & \multicolumn{2}{|c|}{ Exp.3 } & \multicolumn{2}{|c|}{ Exp.1 } & \multicolumn{2}{|c|}{ Exp.2 } & \multicolumn{2}{|c|}{ Exp.1 } & \multicolumn{2}{|c|}{ Exp.2 } \\
\hline & $\begin{array}{l}\text { Nb pl. } \\
\text { inf./pl. } \\
\text { inoc. }{ }^{1}\end{array}$ & $\mathrm{OD} \pm \mathrm{SD}^{2}$ & $\begin{array}{l}\mathrm{Nb} \text { pl. } \\
\text { inf./pl. } \\
\text { inoc. }{ }^{1}\end{array}$ & $\mathrm{OD} \pm \mathrm{SD}^{2}$ & $\begin{array}{l}\mathrm{Nb} \text { pl. } \\
\text { inf./pl. } \\
\text { inoc. }{ }^{1}\end{array}$ & $\mathrm{OD} \pm \mathrm{SD}^{2}$ & $\begin{array}{l}\mathrm{Nb} \text { pl. } \\
\text { inf./pl. } \\
\text { inoc. }{ }^{1}\end{array}$ & $\mathrm{OD} \pm \mathrm{SD}^{2}$ & $\begin{array}{l}\text { Nb pl. } \\
\text { inf./pl. } \\
\text { inoc. }{ }^{1}\end{array}$ & $\mathrm{OD} \pm \mathrm{SD}^{2}$ & $\begin{array}{l}\text { Nb pl. } \\
\text { inf./pl. } \\
\text { inoc. }{ }^{1}\end{array}$ & $\mathrm{OD} \pm \mathrm{SD}^{2}$ & $\begin{array}{l}\text { Nb pl. } \\
\text { inf./pl. } \\
\text { inoc. }{ }^{1}\end{array}$ & $\mathrm{OD} \pm \mathrm{SD}^{2}$ \\
\hline TuYV-RT $T_{\text {GFP }}$ & $4 / 8(50 \%)$ & $1.12 \pm 0.59$ & $13 / 17(76 \%)$ & $0.52 \pm 0.23$ & $4 / 7(57 \%)$ & $0.54 \pm 0$ & $4 / 6(67 \%)$ & $1.42 \pm 0.69$ & $6 / 8(75 \%)$ & $0.70 \pm 0.34$ & $6 / 16(38 \%)$ & $0.31 \pm 0.13$ & $2 / 9(22 \%)$ & $0.69 \pm 0.16$ \\
\hline TuYV & $8 / 8(100 \%)$ & $1.86 \pm 0.30$ & 4/4 (100\%) & $0.63 \pm 0.22$ & $6 / 7(86 \%)$ & $1.61 \pm 0.79$ & $4 / 6(67 \%)$ & $1.58 \pm 0.62$ & $7 / 8(88 \%)$ & $1.90 \pm 0.24$ & $8 / 8(100 \%)$ & $1.70 \pm 0.16$ & $4 / 6(67 \%)$ & $1.40 \pm 1.23$ \\
\hline pbin & $0 / 2$ & $0.14 \pm 0.30$ & $0 / 1$ & 0.11 & $0 / 1$ & 0.15 & $0 / 2$ & $0.13 \pm 0.00$ & $0 / 2$ & $0.11 \pm 0.01$ & $0 / 2$ & $0.10 \pm 0.00$ & $0 / 2$ & $0.12 \pm 0.00$ \\
\hline Non-inoc. ${ }^{3}$ & $0 / 3$ & $0.14 \pm 0.00$ & $0 / 3$ & $0.13 \pm 0.01$ & $0 / 3$ & $0.16 \pm 0.01$ & $0 / 2$ & $0.11 \pm 0.00$ & $0 / 3$ & $0.10 \pm 0.01$ & $0 / 3$ & $0.10 \pm 0.01$ & $0 / 3$ & $0.11 \pm 0.01$ \\
\hline
\end{tabular}

${ }^{1}$ Number of plants infected/plants inoculated. ${ }^{2}$ Mean absorbance values at $405 \mathrm{~nm}$ of the non-inoculated leaves of the infected plants two weeks after inoculation \pm Standard Deviation. A plant is considered infected when the optical density (OD) value of the leaf extract is above the mean OD values of three non-infected plants plus three times the standard deviation of these values. ${ }^{3}$ Non-inoculated plants. The OD value corresponds to the absorbance of the non-inoculated plant. 
The stability of the inserted EGFP sequence in the viral genome was further addressed by analyzing the viral progeny in the three plant species by RT-PCR using the primers already described in the above paragraph. Total RNA was extracted from the systemic leaves of plants inoculated

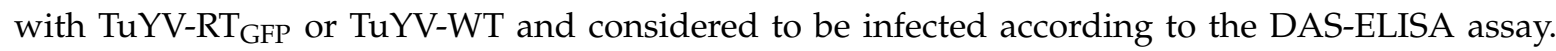

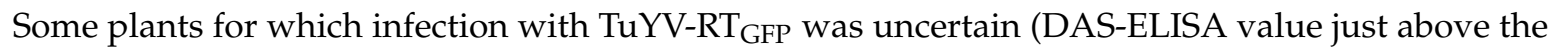
threshold) were also included in the test. A major band of the expected size (1085 bp) was detected in the N. benthamiana plants undoubtedly infected with TuYV-RT GFP (Figure 3a, ELISA OD+) and also in some plants where the presence of the virus was uncertain (Figure 3a, ELISA OD+/-). Surprisingly a very faint band was observed in the ELISA-negative plant (optical density (OD) value below the threshold) (white arrow head in Figure 3a). Since no band was present in the non-inoculated plant or the plant inoculated with the empty vector (Figure 3a), this may be explained by the lack of sensitivity of the immunodetection assay. These results show the conservation of the EGFP complete sequence in the viral progeny (Figure 3a). Additional minor bands of lower size and intensity were, however, present and may correspond to DNA fragments amplified from partially deleted genomes (Figure 3a). A similar situation was found in M. perfoliata, where the expected DNA fragment of $1085 \mathrm{bp}$ was detected in all four plants that reacted positively to DAS-ELISA, but also in the plant for which infection was uncertain (Figure 3b, ELISA OD+/-). In addition, several by-products of lower size were also observed (Figure 3b). In A. thaliana, partial deletions or even the deletion of the entirety of the EGFP sequence in the viral genome were more frequent, suggesting important TuYV-RT $\mathrm{GFP}_{\mathrm{H}}$ genome rearrangements in this plant species. Nevertheless, the $1085 \mathrm{bp}$ fragment corresponding to the complete TuYV-RT $\mathrm{GFP}_{\mathrm{G}}$ genome was detected in three out of eight plants assayed, indicating that the recombinant virus is able to systemically infect Arabidopsis (Figure 3c). The data presented in Figure 3 correspond to the representative experiments.

In a further experiment, the viral progeny of $N$. benthamiana (five plants) infected with TuYV-RT ${ }_{G F P}$ was analyzed by sequencing the DNA fragments produced after RT-PCR from total RNA using the aforementioned primers. The sequencing results confirmed the presence of the viral genome containing the entire EGFP sequence and some deleted forms in N. benthamiana.

In conclusion, these results show that TuYV-RT $\mathrm{GFP}_{\text {is }}$ able to spread in its full-size genome to non-inoculated leaves in the plant species tested. However, the stability of the recombinant genome varies between the plant species, with $N$. benthamiana being the host in which TuYV-RT $\mathrm{GFP}_{\text {undergoes }}$ the least rearrangements. 

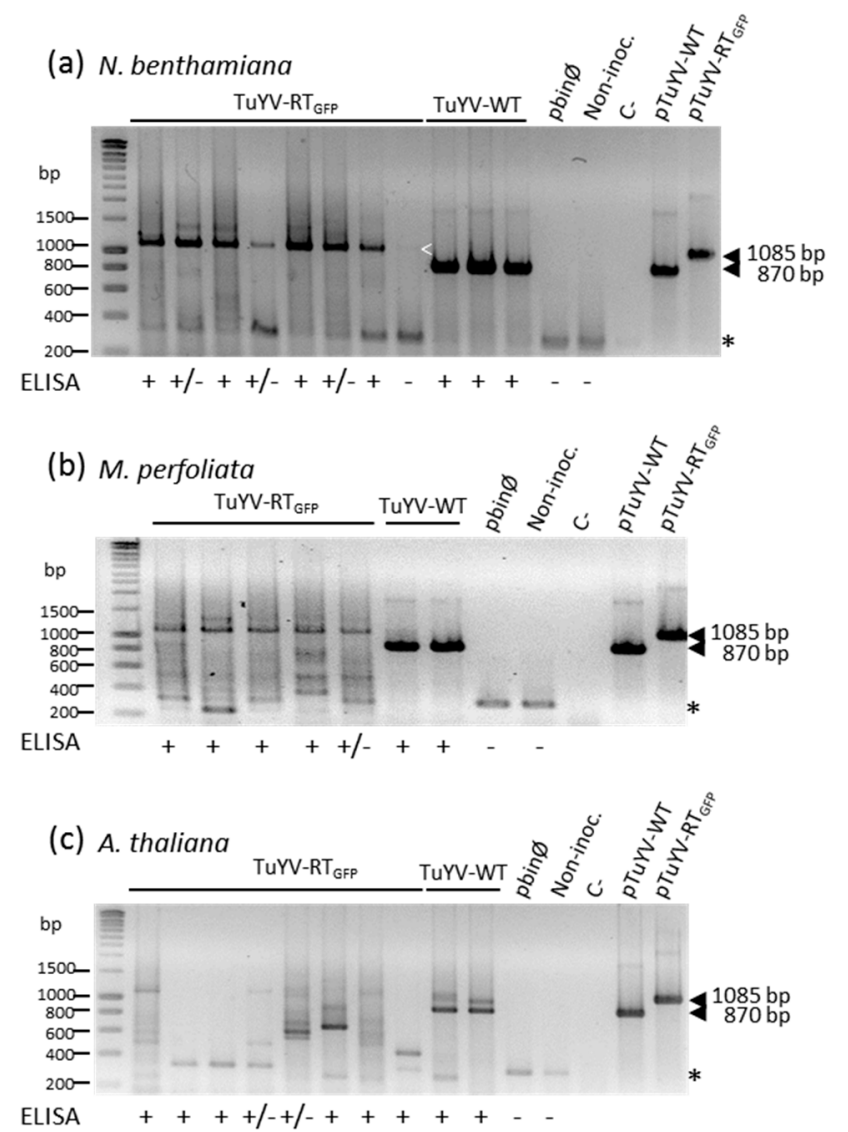

Figure 3. Analysis of viral progeny by reverse transcription-polymerase chain reaction (RT-PCR) in non-inoculated leaves of (a) N. benthamiana; (b) M. perfoliata; and (c) A. thaliana inoculated with

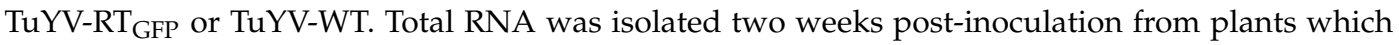
showed an ELISA OD value far above the threshold (ELISA+), just above the threshold $(+/-)$, or below the threshold (-). A primer set was used to amplify a cDNA fragment corresponding to the 3 ' end of TuYV-RT $T_{\text {GFP }}$ and TuYV-WT (FP and RP, Figure 1). PCR products were analyzed by gel electrophoresis and viewed after ethidium bromide staining. The positions of DNA markers are shown on the left. The size of expected fragments is also indicated. pbin-Ø: inoculation with a binary plasmid with no insert;

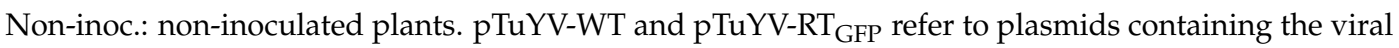
sequences and serve as positive controls. C-: PCR control without CDNA. *: non-specific amplification; White open arrow-head: faint DNA amplification.

\subsection{Aphid Transmissibility of TuYV-RT $T_{G F P}$}

The ability of TuYV-RT $\mathrm{GFP}_{\text {to }}$ to transmitted by aphids was assessed by feeding $M$. persicae on an artificial medium containing similar amounts of TuYV-RT $\mathrm{GFP}_{\mathrm{GP}}$ or TuYV-WT purified particles. The viruliferous aphids were then transferred to N. benthamiana, M. perfoliata, or A. thaliana for virus inoculation, and the test plants were analyzed by DAS-ELISA two weeks later. TuYV-RT $\mathrm{GFP}_{\mathrm{G}}$ was readily

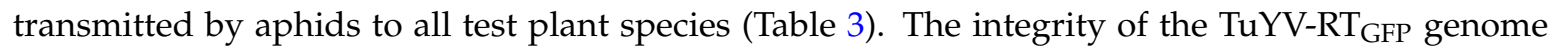
present in the aphid-inoculated plants was tested as aforementioned by RT-PCR. As previously

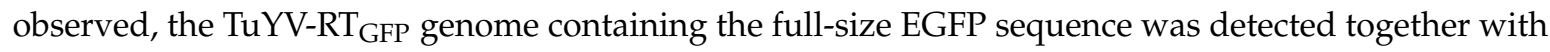
genome-deleted forms (Figure S3). 


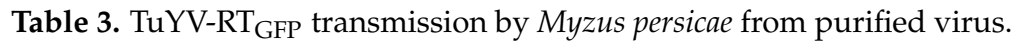

\begin{tabular}{|c|c|c|c|c|}
\hline & \multirow{2}{*}{$\begin{array}{c}\text { N. } \text { benthamiana }^{1} \\
\text { Exp.1 }\end{array}$} & \multicolumn{2}{|c|}{ M. perfoliata ${ }^{1}$} & \multirow{2}{*}{$\begin{array}{c}\text { A. } \text { thaliana }^{1} \\
\text { Exp.1 }\end{array}$} \\
\hline & & $\operatorname{Exp.1}$ & $\operatorname{Exp.2}$ & \\
\hline & $\mathrm{Nb}$ pl.inf./pl. inoc. & $\begin{array}{l}\mathrm{Nb} \text { pl.inf./pl. } \\
\text { inoc. }^{2}\end{array}$ & $\begin{array}{l}\mathrm{Nb} \text { pl.inf./pl. } \\
\text { inoc. }^{2}\end{array}$ & $\begin{array}{l}\mathrm{Nb} \text { pl.inf./pl. } \\
\text { inoc. }^{2}\end{array}$ \\
\hline TuYV-RT $_{\text {GFP }}$ & $10 / 10$ & $9 / 10$ & $5 / 10$ & $4 / 10$ \\
\hline TuYV-WT & $9 / 10$ & $10 / 10$ & $10 / 10$ & $10 / 10$ \\
\hline Non-inoc. 3 & $0 / 3$ & $0 / 3$ & $0 / 3$ & $0 / 3$ \\
\hline
\end{tabular}

\subsection{In Vivo Tracking of TuYV-RT $T_{G F P}$ Following Agroinoculation or Aphid Transmission}

To evaluate whether TuYV-RT $\mathrm{GFP}_{\mathrm{GP}}$ could be used to track virus localization in infected plants, epifluorescence microscopy observations were conducted in the agroinoculated leaves of N. benthamiana. In most cases, groups of epidermal fluorescent cells were observed (Figure 4a). The fluorescence was present diffusely throughout the cytoplasm and in granules lining the plasma membrane (Figure 4b). Similar distribution has been reported for the GFP-labeled Potato leafroll virus (PLRV) in the inoculated leaves of N. clevelandii or N. benthamiana [30]. The microscopic observations also clearly revealed fluorescent foci in perinuclear localizations that could be membrane-derived (Figure 4c). The observations were then carried out on non-inoculated leaves of infected N. benthamiana, M. perfoliata, and A. thaliana two to three weeks after agroinoculation. The GFP fluorescence was

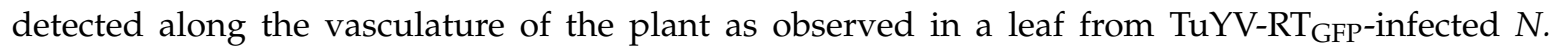
benthamiana at a low magnification (Figure $4 \mathrm{~d}$ ).

A similar pattern of fluorescence labeling the plant vasculature was also obtained when observing whole plants using an epifluorescence macroscope (Figure S4a,b). At a higher magnification with an epifluorescence microscope, observations of the longitudinal sections of petioles or of isolated vein networks showed fluorescence in elongated cells in the veins of the three plant species (Figure 4e, Figure S4c,d) or in phloem cells surrounding the xylem (Figure 4f). Importantly, no fluorescence was

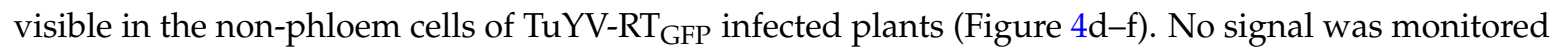
in similar sections or leaf discs from N. benthamiana, M. perfoliata, or A. thaliana infiltrated with the empty binary vector (Figure $4 \mathrm{a}-\mathrm{f}$ and Figure $\mathrm{S} 4 \mathrm{c}, \mathrm{d}$, right panels).

When TuYV-RT $\mathrm{GFP}_{\text {was }}$ delivered to M. perfoliata by aphids, isolated fluorescent epidermal cells with a notched shape were observed in the confined zone where the aphids were deposited (Figure $5 \mathrm{a}-\mathrm{c}$ ). These cells likely represent cells punctured by M. persicae during the probing phase, in which the virus was delivered and replicated. Similarly, as was reported for a GFP-tagged PLRV genome [30], the fluorescence was always confined to isolated cells and never extended to adjacent cells, thus confirming the inability of TuYV to move to neighbouring non-phloem cells. Similar observations of isolated fluorescent cells were made on the aphid-inoculated leaves of $A$. thaliana (not shown). Interestingly, on the aphid-inoculated leaves of $M$. perfoliata, in addition to the isolated epidermal cells (open arrow in Figure 5c), elongated consecutive fluorescent cells lining the veins were also observed in a plane underneath, suggesting viral replication in phloem cells (Figure 5c). These infected phloem cells likely represent the true primary infection sites from which TuYV may spread to adjacent cells. 


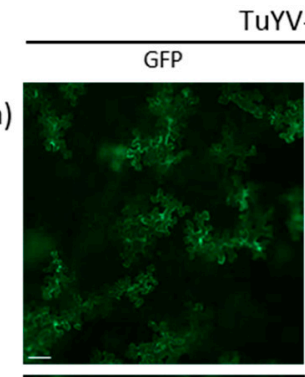

UYV-RT GFP

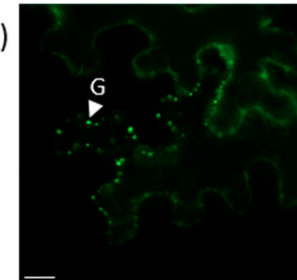

(c)
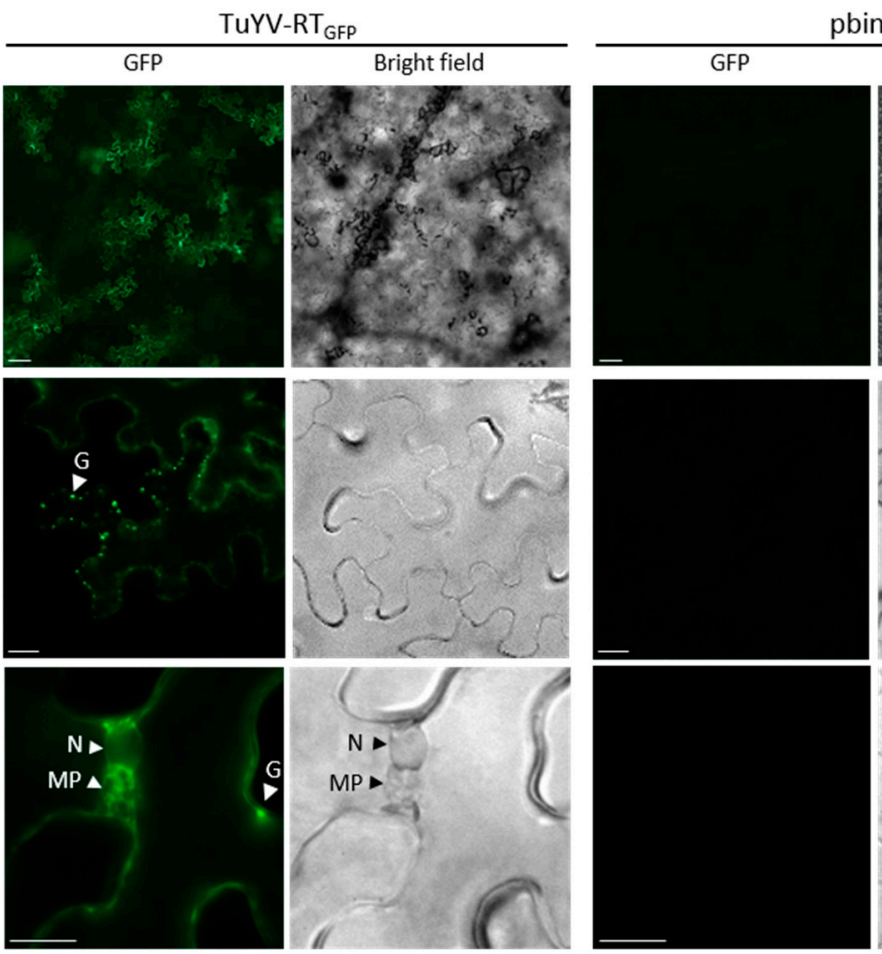

pbin- $\varnothing$
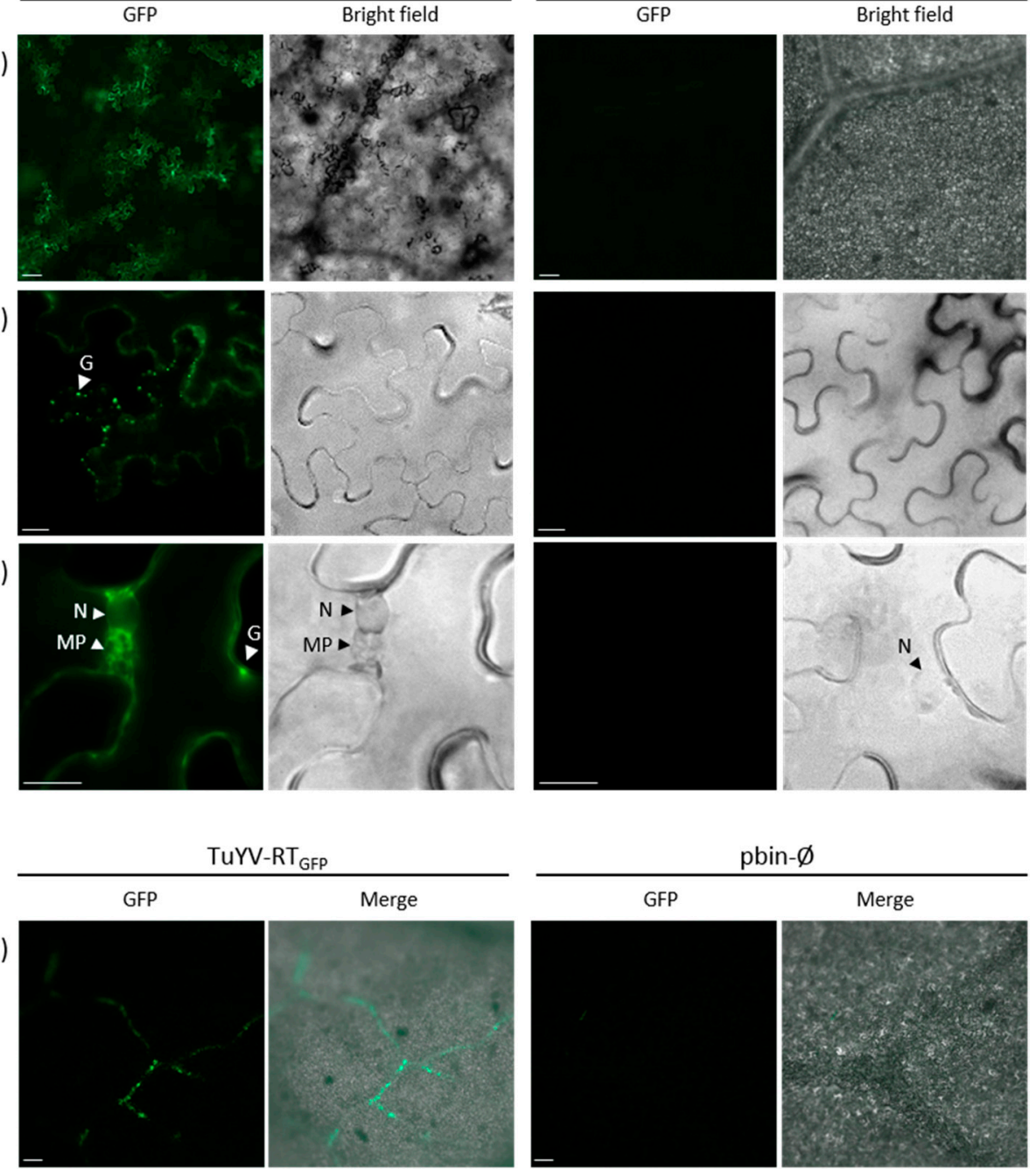

UYV-RT GFP

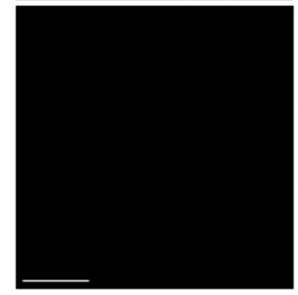

(e)
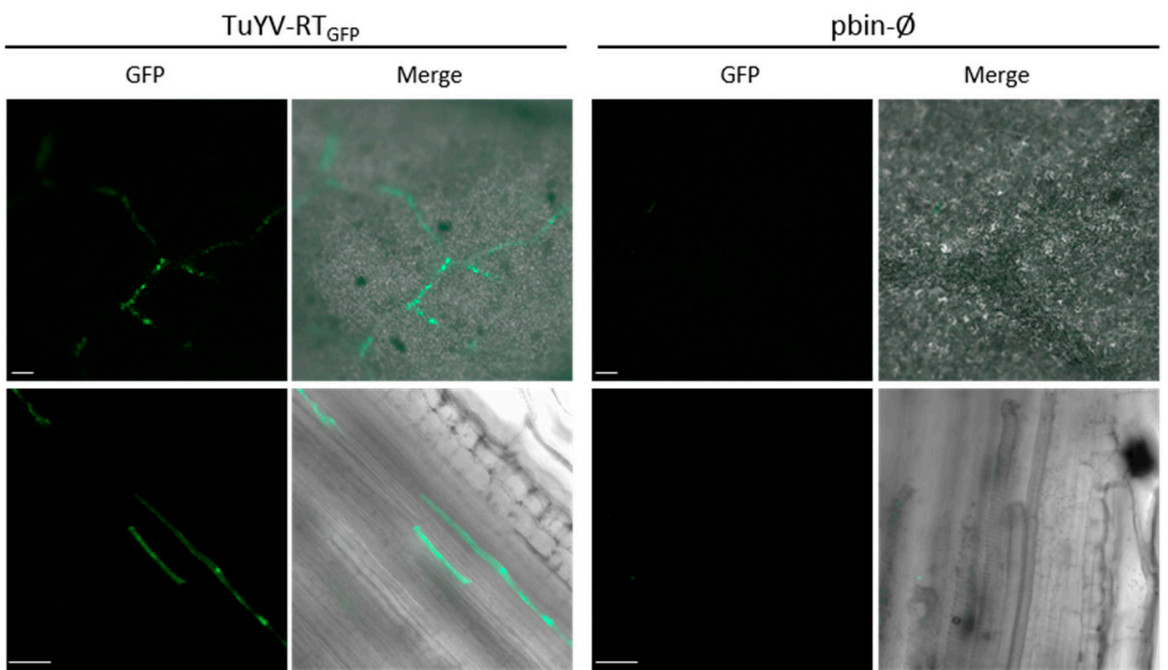

(d) Merge
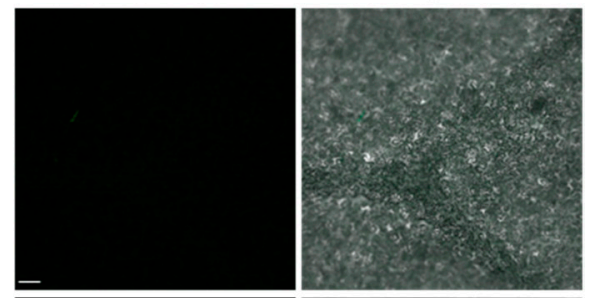

(f)
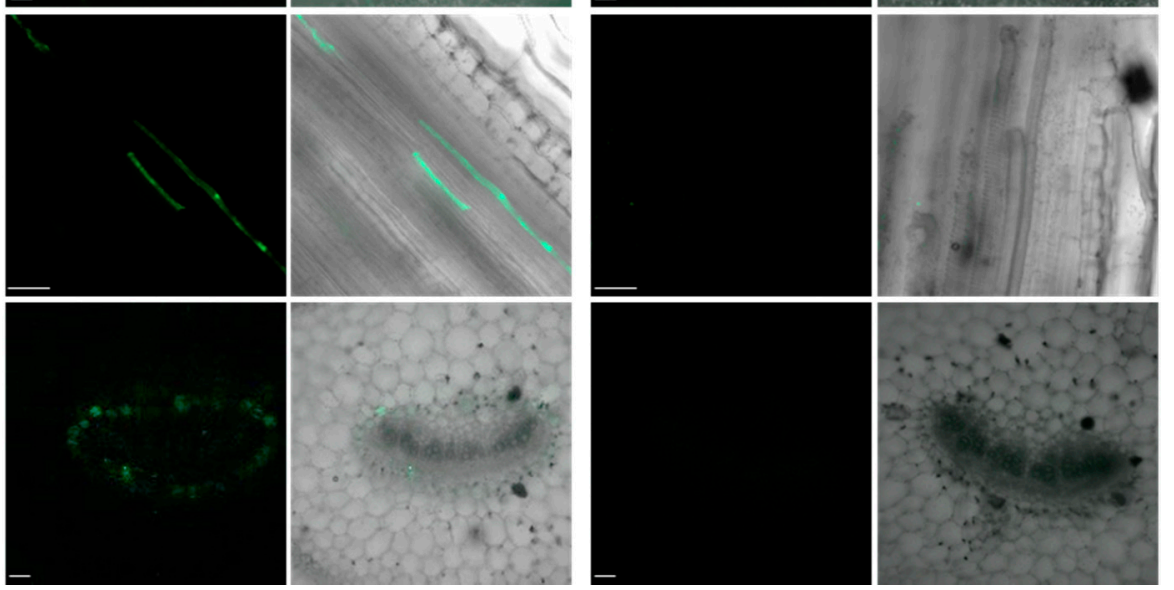

Figure 4. Cellular localization of EGFP fluorescence $(\mathbf{a}-\mathbf{c})$ in agroinoculated leaves and (d-f) in non-inoculated leaves of $N$. benthamiana agroinfiltrated with TuYV-RT $\mathrm{GFP}_{\text {. N }}$. benthamiana leaf (d) petiole, (e) longitudinal, or (f) transversal sections. The observations were performed with an epifluorescence microscope and in similar conditions on plant material infiltrated with pbin- $\varnothing$ (last two columns on the right). Bright field observations are also shown to better locate the nucleus (second and fourth column for $(\mathbf{a}-\mathbf{c})$ ), and the merge images of the bright field and the GFP emission are shown for $(\mathbf{d}-\mathbf{f})$ (second and fourth column). The scale bars are $20 \mu \mathrm{m}$ for $(\mathbf{b}, \mathbf{c})$ and $100 \mu \mathrm{m}$ for $(\mathbf{a}, \mathbf{d}-\mathbf{f})$. (f) is an optical section obtained with structured illumination (ApoTome, Zeiss, Marly-le-Roi, France). N: nucleus; G: granules; MP: membrane proliferation. 

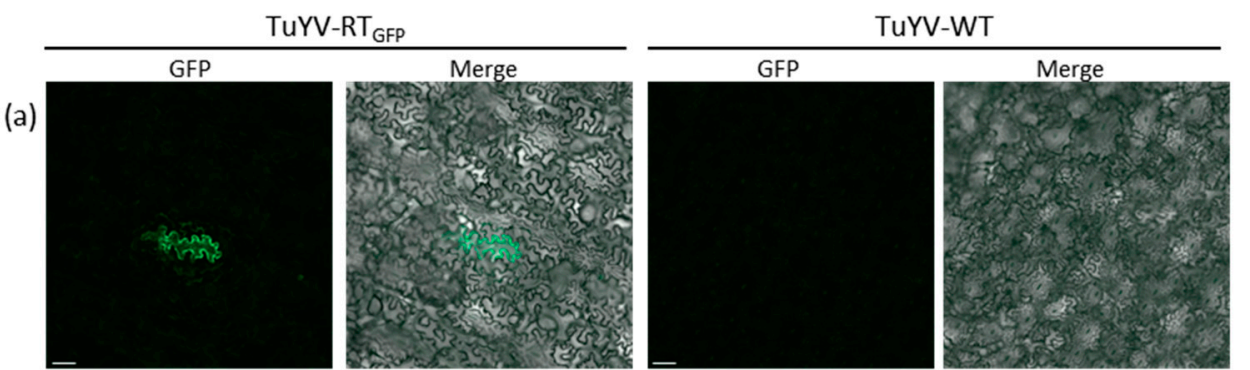

(b)
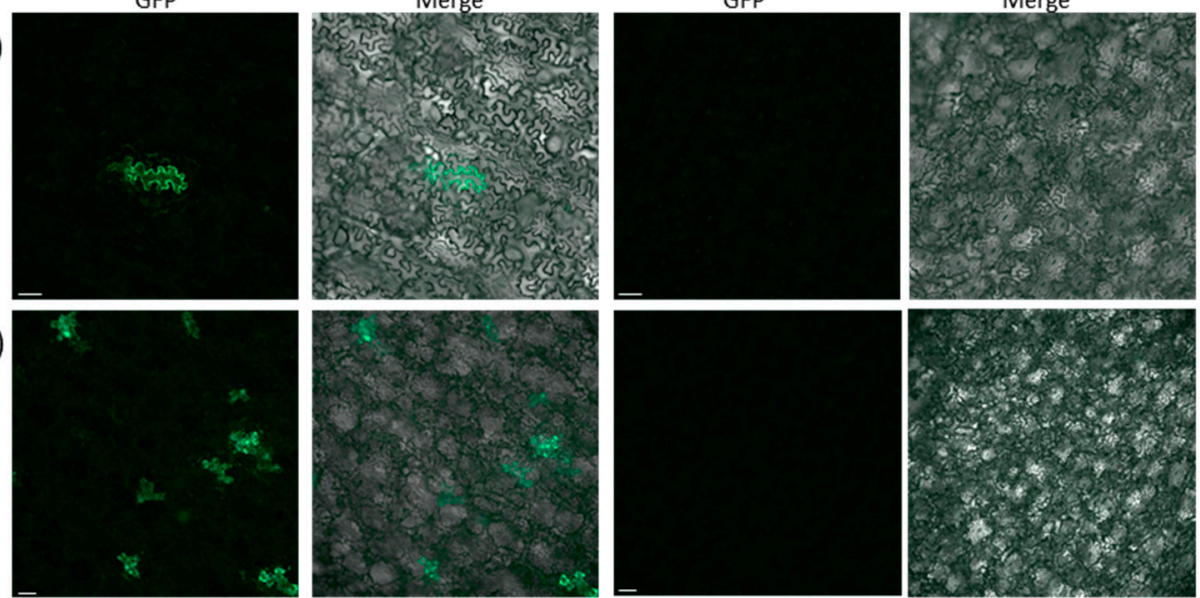

(c)
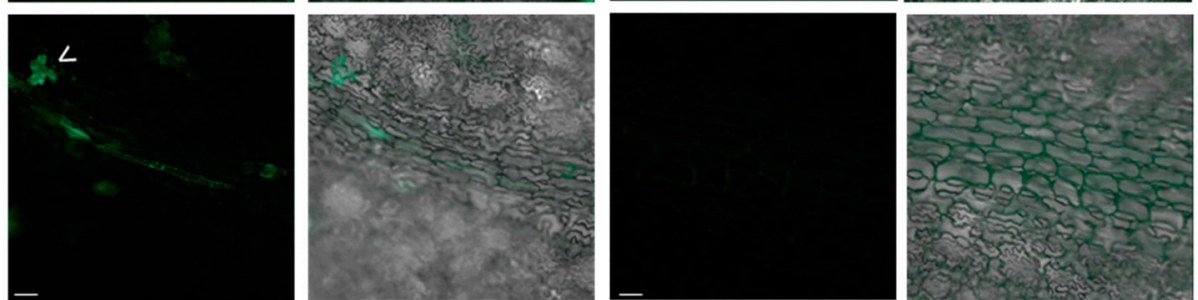

(d)
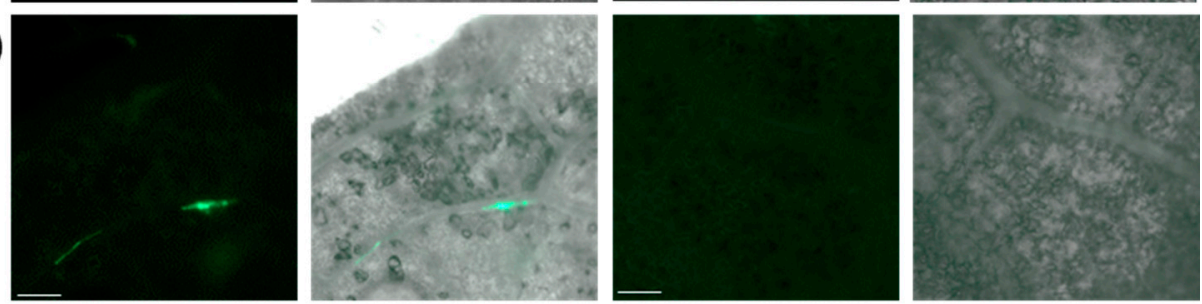

(e)
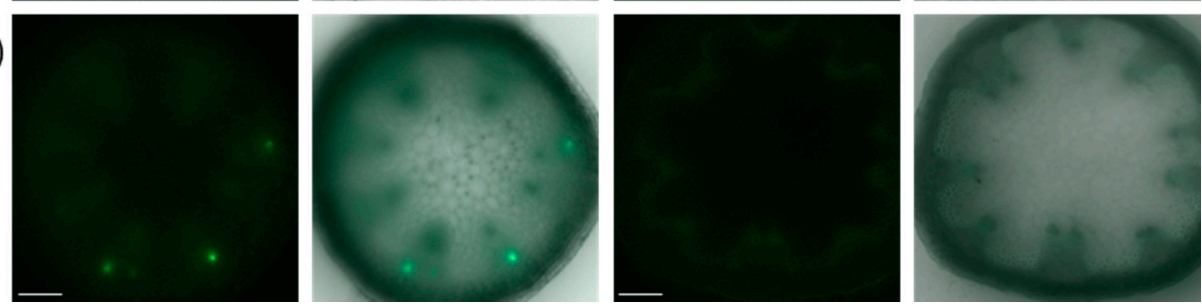

Figure 5. Cellular localization of EGFP fluorescence in the inoculated or systemic leaves of infected plants after aphid delivery of TuYV-RT $\mathrm{GFP}_{\text {f }}$ or TuYV-WT. (a-c) Cellular localization of EGFP in $M$. perfoliata inoculated leaves five days after aphid inoculation. Cellular localization of EGFP in a non-inoculated (d) leaf and (e) stem of $A$. thaliana two weeks after virus delivery by aphids. The observations were performed with an epifluorescence microscope and in similar conditions on plant material inoculated with TuYV-WT (last two columns on the right). Merge images of the bright field and the GFP emission are also shown (second and fourth column). White open arrow-head: isolated infected epidermal cells. Scale bars are $100 \mu \mathrm{m}$.

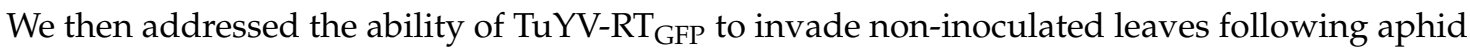
inoculation. To facilitate fluorescence observation in the veins, the epidermis of $A$. thaliana leaves was peeled off. Fluorescent cells were detected along the veins (Figure $5 \mathrm{~d}$ ), and fluorescent foci were also observed in a transversal section of a flowering stem of infected $A$. thaliana (Figure 5e). In this case, the fluorescent foci were located at the periphery of the stem section where the vascular bundles are located (Figure 5e). No signal was monitored in the leaves of plants inoculated with aphids carrying TuYV-WT (Figure 5a-e, right panels). 
Free GFP was reported to be able to spread by passive diffusion through expanding tissues [43,44].

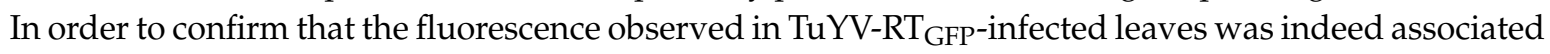
to virus replication, the leaf samples were first observed by epifluorescence microscopy and then tested by DAS-ELISA or RT-PCR to detect the presence of the virus or the viral RNA. Leaf discs were collected from 15 non-inoculated leaves of three $N$. benthamiana infected with TuYV-RT GFP (positive by DAS-ELISA two weeks after agroinoculation). In 12 out of 15 leaves analyzed, the detection of the virus correlated perfectly with the fluorescence observation. In two leaves however, although no fluorescence was observed, the full-size viral genome containing the EGFP sequence was detected in one of the samples by RT-PCR, likely denoting a lack of sensitivity of the fluorescence detection system. Finally, one leaf displayed several fluorescent foci, but no viral genome was detected (data not shown).

\section{Discussion}

Tracking fluorescent viruses in plants has proven to be a valuable tool to study the critical steps of the viral cycle involved in virus replication or movement in compatible or incompatible host interactions [45-51]. This approach was also developed to observe the initial stages of virus infection following aphid transmission of a non-persistently transmitted virus [52]. In addition, cellular and subcellular localizations of GFP-fused viral proteins were conducted after inserting the GFP sequence into a viral genome [53-56]. However, the insertion of the fluorochrome sequence into a viral genome has always been a challenge since it can reduce the infectivity of the fluorescent virus or generate virus-deleted forms impaired in their ability to move systemically [57-61]. Introducing non-viral sequences into a viral genome can become particularly difficult for viruses with icosaedric particles, as they are often subject to high constraints of genome size for efficient encapsidation $[62,63]$.

The present study reports the first fluorescently tagged virus in the Luteoviridae family that successfully develops a systemic infection in several plant species after agroinoculation or aphid

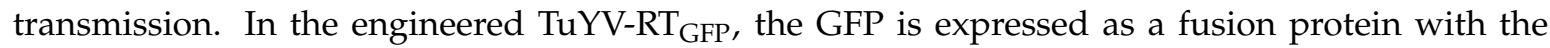
$\mathrm{N}$-terminal part of the RT protein. Importantly the full-size recombinant genome was recovered in the viral progeny from $N$. benthamiana and $M$. perfoliata, indicating its stability in these host plants.

Attempts to obtain a GFP-tagged infectious clone of Potato leafroll virus (PLRV), a member of the Luteoviridae family, were formerly reported. A clone in which the 48 last amino acids of the RT protein were removed and replaced by the GFP sequence was shown to be infectious, but the genome proved to be unstable as large deletions encompassing the GFP insert were reported [30]. Although the strategy developed by Nurkiyanova et al. shares similarities with the one we used to generate TuYV-RT $\mathrm{GFP}_{\text {[30], the engineered PLRV-GFP had a larger genome size compared to TuYV-RT }} \mathrm{GFP}_{\text {, which }}$ could explain some genome instability and therefore its inability to develop a fluorescent systemic infection in plants after aphid transmission or agroinoculation. An engineered Beet mild yellowing virus (BMYV, family Luteoviridae) tagged with GFP was also obtained, but its infectivity was only evaluated in A. thaliana protoplasts after the inoculation of viral-derived transcripts [31].

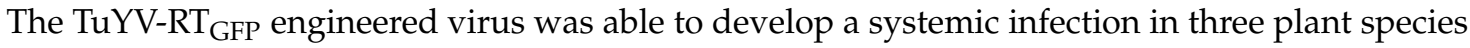
tested, N. benthamiana, M. perfoliata, and A. thaliana, when delivered by agrobacteria or by aphids. The presence of a full-length RT protein, although not mandatory, is required for efficient polerovirus systemic movement $[19,24,25]$. The lack of the C-terminal part of the RT protein may therefore be responsible for the lower infectivity of TuYV-RT $\mathrm{GFP}_{\mathrm{G}}$ observed more specifically in A. thaliana. Alternatively, the GFP moiety present at the C-terminal might generate some physical hindrance and/or epitope hindrance during viral movement. Moreover, we cannot exclude that the additional non-viral and non-EGFP sequences in the TuYV-RT $\mathrm{GFP}_{\mathrm{GF}}$ construct can have an effect on virus replication and systemic movement.

Full-length GFP-tagged viral genomes were easily recovered in the systemic leaves of infected M. perfoliata and N. benthamiana plants. However, deleted viral genomes, the abundance of which varied depending on the plant species, were also retrieved. In particular, viral genomic rearrangements, resulting in the loss of the GFP sequence integrity, were more frequent in A. thaliana, but the presence 
of these deleted viral genomes did not prevent the invasion of the plant by the complete TuYV-RT $\mathrm{GFP}_{\mathrm{G}}$ genome. Whether these genome alterations are related to host-specific functions of the RT protein requires further investigation. Aphid transmission of TuYV-RT $\mathrm{GFP}_{\text {was }}$ also successfully achieved as fluorescent foci were detected in systemic leaves. This confirms the dispensable nature of the C-terminal domain of the polerovirus RTD for aphid transmission [22,24].

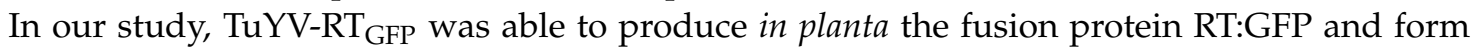
virions with a protein composition similar to the wild-type virus. As expected, the EGFP moiety was absent from virions, since only the cleaved form RT*, which does not contain the GFP, is present in viral particles. Surprisingly, Nurkiyanova et al. [30] reported the presence of the RT:GFP fusion protein in particles of PLRV, which suggests that, in this particular case, the insertion of the GFP sequence into the PLRV genome might have impaired the correct cleavage of the RT protein.

Microscopic observations performed on agroinoculated $N$. benthamiana leaves localized the RT:GFP produced by TuYV-RT $\mathrm{GFP}_{\mathrm{GP}}$ diffusely in the cytoplasm or as granules at the periphery of the cell. Fluorescent structures were also observed in the vicinity of the nucleus. These structures looked like membrane proliferations and could be sites of viral replication or encapsidation [64]. Considering that the RT:GFP is a C-terminal truncated form of the complete RT and resembles the RT* incorporated into virions, this represents the first sub-cellular observations of the truncated RT protein expressed from a viral clone. Similar localizations were obtained for the almost complete RT:GFP from PLRV. Although this protein localizes to the nucleolus when expressed alone, it was excluded from the nucleus in the viral context [65]. Microscopic observations performed on M. perfoliata leaves inoculated with

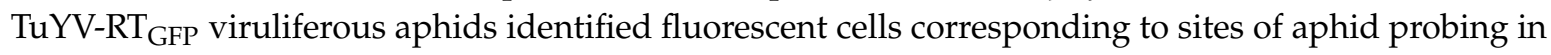
the epidermis and in infected elongated phloem cells. While the epidermal cells were always isolated, which is in accordance with the inability of the virus to move from these cells to adjacent cells, the fluorescent phloem cells were observed to be aligned in a row, suggesting viral trafficking between vascular cells. In a few instances, the fluorescent epidermal and phloem cells were observed in close proximity, suggesting that they might have got infected from the same aphid, and could therefore represent the presumed primary infection sites in the vasculature. When searching for food, the aphid punctures the epidermal cells for probing before inserting intercellularly its stylets to reach the phloem cells, where the virus is inoculated and replicates. It has been shown that several cells along the stylet path can be punctured [66], but, in our experiments, we did not observe fluorescent cells other than epidermal and phloem cells.

In newly developed leaves of $N$. benthamiana, M. perfoliata, and A. thaliana plants following inoculation by agrobacteria or aphids, the fluorescently tagged TuYV was also strictly observed in the cells of the vasculature. As the entire RT:GFP protein was not found incorporated into TuYV-RT $\mathrm{GFP}_{\mathrm{G}}$ particles, the observed fluorescence likely corresponds to viral multiplication sites. It could be conceivable that some of the fluorescent signals also arise from free GFP, released after the cleavage of the RT:GFP to produce the RT* incorporated into virions, spreading by passive diffusion through expanding tissues $[43,44]$. However, this hypothesis seems unlikely since we showed that in almost all non-inoculated leaves, fluorescence emission correlated with virus detection. In addition, in contrast to previous observations on the post-phloem transport of the GFP [43,44], fluorescence trafficking from the phloem cells into adjacent mesophyll cells was never detected in our study. This observation indicates that the GFP fragment cleaved from RT:GFP is likely degraded, similar to the C-terminal part of the RT that has never been detected by western blot in infected tissues. This reinforces

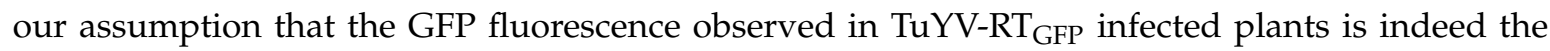
consequence of virus replication rather than the passive translocation of free GFP. The detection of

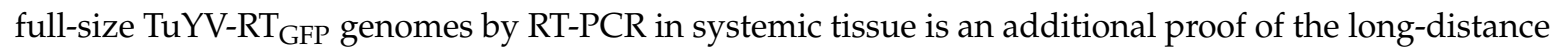
movement of TuYV-RT $\mathrm{GFP}_{\text {. }}$

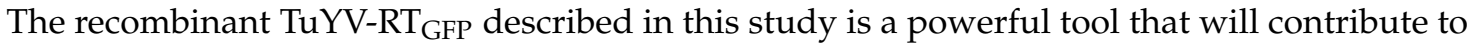
future advances in the functional analysis of viral and host genes involved in the polerovirus cycle in planta and in polerovirus transmission by aphids. 
Supplementary Materials: The following are available online at www.mdpi.com/1999-4915/9/5/166/s1,

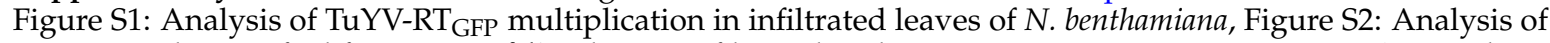

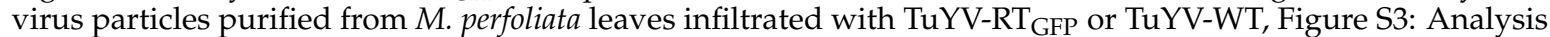
of viral progeny by RT-PCR in non-inoculated leaves of M. perfoliata and A. thaliana inoculated by aphids with TuYV-RT $\mathrm{GFP}_{\mathrm{P}}$ or TuYV-WT, Figure S4: Cellular localization of EGFP fluorescence emitted by TuYV-RT $\mathrm{GFP}_{\text {inoculated }}$ to plants by agroinoculation, Table S1: List of primers.

Acknowledgments: We greatly thank Catherine Reinbold (INRA, Colmar, France) for transmission electron microscopy observations of the purified viruses. We are also grateful to Marion Clavel (IBMP, Strasbourg, France) for technical advice to strip the epidermis and collect the veins of $A$. thaliana before the fluorescence observations. We would also like to thank Nicole Bochet and the members of the experimental unit of INRA-Colmar (France) for their valuable technical assistance with aphid rearing and plant production. Pauline Rigo (IBMP, Strasbourg) is acknowledged for her help in protoplast infection and analysis. This project was financed by the French National Agency for Research (ANR) in the frame of the Viraphiplant project (ANR-14-CE19-0010-01). Céline Sorin was financed in the frame of the ANR-06-BLAN066-0009 P0-SUPP.

Author Contributions: S.B., E.P., C.S., C.P. and D.S. performed the experiments. V.Z.-G., S.B., C.S. and V.B. designed the experiments. V.B., V.Z.-G. and S.B. wrote the paper.

Conflicts of Interest: The authors declare no conflict of interest.

\section{References}

1. Beuve, M.; Stevens, M.; Liu, H.Y.; Wintermantel, W.M.; Hauser, S.; Lemaire, O. Biological and molecular characterization of an american sugar beet-infecting Beet western yellows virus isolate. Plant Dis. 2008, 92, 51-60. [CrossRef]

2. Smirnova, E.; Firth, A.E.; Miller, W.A.; Scheidecker, D.; Brault, V.; Reinbold, C.; Rakotondrafara, A.M.; Chung, B.Y.; Ziegler-Graff, V. Discovery of a small non-aug-initiated ORF in poleroviruses and luteoviruses that is required for long-distance movement. PLoS Pathog. 2015, 11, e1004868. [CrossRef] [PubMed]

3. D'Arcy, C.J.; De Zoeten, G.A. Beet yellows western virus in phloem tissue of Thlaspi arvense. Phytopathology 1979, 69, 1194-1198. [CrossRef]

4. Esau, K.; Hoefert, L.L. Ultrastructure of sugarbeet leaves infected with beet western yellows virus. J. Ultrastruct. Res. 1972, 40, 556-571. [CrossRef]

5. Mutterer, J.D.; Stussi-Garaud, C.; Michler, P.; Richards, K.E.; Jonard, G.; Ziegler-Graff, V. Role of the beet western yellows virus readthrough protein in virus movement in Nicotiana clevelandii. J. Gen. Virol. 1999, 80, 2771-2778. [CrossRef] [PubMed]

6. Shepardson, S.; Esau, K.; McCrum, R. Ultrastructure of potato leaf phloem infected with potato leafroll virus. Virology 1980, 105, 379-392. [CrossRef]

7. Brault, V.; Uzest, M.; Monsion, B.; Jacquot, E.; Blanc, S. Aphids as transport devices for plant viruses. C. R. Biol. 2010, 333, 524-538. [CrossRef] [PubMed]

8. Brault, V.; Herrbach, E.; Reinbold, C. Electron microscopy studies on luteovirid transmission by aphids. Micron 2007, 38, 302-312. [CrossRef] [PubMed]

9. Baumberger, N.; Tsai, C.H.; Lie, M.; Havecker, E.; Baulcombe, D.C. The polerovirus silencing suppressor P0 targets argonaute proteins for degradation. Curr. Biol. 2007, 17, 1609-1614. [CrossRef] [PubMed]

10. Bortolamiol, D.; Pazhouhandeh, M.; Marrocco, K.; Genschik, P.; Ziegler-Graff, V. The polerovirus F box protein P0 targets ARGONAUTE1 to suppress RNA silencing. Curr. Biol. 2007, 17, 1615-1621. [CrossRef] [PubMed]

11. Csorba, T.; Lozsa, R.; Hutvagner, G.; Burgyan, J. Polerovirus protein P0 prevents the assembly of small RNA-containing RISC complexes and leads to degradation of ARGONAUTE1. Plant J. 2010, 62, 463-472. [CrossRef] [PubMed]

12. Derrien, B.; Baumberger, N.; Schepetilnikov, M.; Viotti, C.; De Cillia, J.; Ziegler-Graff, V.; Isono, E.; Schumacher, K.; Genschik, P. Degradation of the antiviral component argonaute1 by the autophagy pathway. Proc. Natl. Acad. Sci. USA 2012, 109, 15942-15946. [CrossRef] [PubMed]

13. Pazhouhandeh, M.; Dieterle, M.; Marrocco, K.; Lechner, E.; Berry, B.; Brault, V.; Hemmer, O.; Kretsch, T.; Richards, K.E.; Genschik, P.; et al. F-box-like domain in the polerovirus protein P0 is required for silencing suppressor function. Proc. Natl. Acad. Sci. USA 2006, 103, 1994-1999. [CrossRef] [PubMed] 
14. Prüfer, D.; Kawchuk, L.; Monecke, M.; Nowok, S.; Fischer, R.; Rohde, W. Immunological analysis of potato leafroll luteovirus (PLRV) P1 expression identifies a $25 \mathrm{kDa}$ RNA-binding protein derived via P1 processing. Nucleic Acids Res. 1999, 27, 421-425. [CrossRef] [PubMed]

15. Van der Wilk, F.; Verbeek, M.; Dullemans, A.M.; van den Heuvel, J.F. The genome-linked protein of potato leafroll virus is located downstream of the putative protease domain of the ORF1 product. Virology 1997, 234, 300-303. [CrossRef] [PubMed]

16. Bahner, I.; Lamb, J.; Mayo, M.A.; Hay, R.T. Expression of the genome of potato leafroll virus: Readthrough of the coat protein termination codon in vivo. J. Gen. Virol. 1990, 71, 2251-2256. [CrossRef] [PubMed]

17. Brault, V.; van den Heuvel, J.F.; Verbeek, M.; Ziegler-Graff, V.; Reutenauer, A.; Herrbach, E.; Garaud, J.C.; Guilley, H.; Richards, K.; Jonard, G. Aphid transmission of beet western yellows luteovirus requires the minor capsid read-through protein P74. EMBO J. 1995, 14, 650-659. [PubMed]

18. Wang, J.Y.; Chay, C.; Gildow, F.E.; Gray, S.M. Readthrough protein associated with virions of barley yellow dwarf luteovirus and its potential role in regulating the efficiency of aphid transmission. Virology 1995, 206, 954-962. [CrossRef] [PubMed]

19. Boissinot, S.; Erdinger, M.; Monsion, B.; Ziegler-Graff, V.; Brault, V. Both structural and non-structural forms of the readthrough protein of cucurbit aphid-borne yellows virus are essential for efficient systemic infection of plants. PLoS ONE 2014, 9, e93448. [CrossRef] [PubMed]

20. Brault, V.; Bergdoll, M.; Mutterer, J.; Prasad, V.; Pfeffer, S.; Erdinger, M.; Richards, K.E.; Ziegler-Graff, V. Effects of point mutations in the major capsid protein of beet western yellows virus on capsid formation, virus accumulation, and aphid transmission. J. Virol. 2003, 77, 3247-3256. [CrossRef] [PubMed]

21. Brault, V.; Mutterer, J.; Scheidecker, D.; Simonis, M.T.; Herrbach, E.; Richards, K.; Ziegler-Graff, V. Effects of point mutations in the readthrough domain of the beet western yellows virus minor capsid protein on virus accumulation in planta and on transmission by aphids. J. Virol. 2000, 74, 1140-1148. [CrossRef] [PubMed]

22. Bruyère, A.; Brault, V.; Ziegler-Graff, V.; Simonis, M.T.; Van den Heuvel, J.F.; Richards, K.; Guilley, H.; Jonard, G.; Herrbach, E. Effects of mutations in the beet western yellows virus readthrough protein on its expression and packaging and on virus accumulation, symptoms, and aphid transmission. Virology 1997, 230, 323-334. [CrossRef] [PubMed]

23. Peter, K.A.; Gildow, F.; Palukaitis, P.; Gray, S.M. The C terminus of the polerovirus P5 readthrough domain limits virus infection to the phloem. J. Virol. 2009, 83, 5419-5429. [CrossRef] [PubMed]

24. Peter, K.A.; Liang, D.; Palukaitis, P.; Gray, S.M. Small deletions in the potato leafroll virus readthrough protein affect particle morphology, aphid transmission, virus movement and accumulation. J. Gen. Virol. 2008, 89, 2037-2045. [CrossRef] [PubMed]

25. Rodriguez-Medina, C.; Boissinot, S.; Chapuis, S.; Gereige, D.; Rastegar, M.; Erdinger, M.; Revers, F.; Ziegler-Graff, V.; Brault, V. A protein kinase binds the C-terminal domain of the readthrough protein of Turnip yellows virus and regulates virus accumulation. Virology 2015, 486, 44-53. [CrossRef] [PubMed]

26. Hofius, D.; Herbers, K.; Melzer, M.; Omid, A.; Tacke, E.; Wolf, S.; Sonnewald, U. Evidence for expression level-dependent modulation of carbohydrate status and viral resistance by the potato leafroll virus movement protein in transgenic tobacco plants. Plant J. 2001, 28, 529-543. [CrossRef] [PubMed]

27. Lee, L.; Palukaitis, P.; Gray, S.M. Host-dependent requirement for the potato leafroll virus 17-kDa protein in virus movement. Mol. Plant Microbe Interact. 2002, 15, 1086-1094. [CrossRef] [PubMed]

28. Vogel, F.; Hofius, D.; Sonnewald, U. Intracellular trafficking of potato leafroll virus movement protein in transgenic arabidopsis. Traffic 2007, 8, 1205-1214. [CrossRef] [PubMed]

29. Ziegler-Graff, V.; Brault, V.; Mutterer, J.; Simonis, M.T.; Herrbach, E.; Guilley, H.; Richards, K.; Jonard, G. The coat protein of beet western yellows luteovirus is essential for systemic infection but the viral gene products P29 and P19 are dispensable for systemic infection and aphid transmission. Mol. Plant Microbe Interact. 1996, 9, 501-510. [CrossRef]

30. Nurkiyanova, K.M.; Ryabov, E.V.; Commandeur, U.; Duncan, G.H.; Canto, T.; Gray, S.M.; Mayo, M.A.; Taliansky, M.E. Tagging potato leafroll virus with the jellyfish green fluorescent protein gene. J. Gen. Virol. 2000, 81, 617-626. [CrossRef] [PubMed]

31. Stevens, M.; Vigano, F. Production of a full-length infectious GFP-tagged cDNA clone of beet mild yellowing virus for the study of plant-polerovirus interactions. Virus Genes 2007, 34, 215-221. [CrossRef] [PubMed]

32. Zhang, G.; Gurtu, V.; Kain, S.R. An enhanced green fluorescent protein allows sensitive detection of gene transfer in mammalian cells. Biochem. Biophys. Res. Commun. 1996, 227, 707-711. [CrossRef] [PubMed] 
33. Leiser, R.M.; Ziegler-Graff, V.; Reutenauer, A.; Herrbach, E.; Lemaire, O.; Guilley, H.; Richards, K.; Jonard, G. Agroinfection as an alternative to insects for infecting plants with beet western yellows luteovirus. Proc. Natl. Acad. Sci. USA 1992, 89, 9136-9140. [CrossRef] [PubMed]

34. Holsters, M.; Silva, B.; Van Vliet, F.; Genetello, C.; De Block, M.; Dhaese, P.; Depicker, A.; Inze, D.; Engler, G.; Villarroel, R.; et al. The functional organization of the nopaline A. Tumefaciens plasmid pTIC58. Plasmid 1980, 3, 212-230. [CrossRef]

35. English, J.J.; Davenport, G.F.; Elmayan, T.E.; Vaucheret, H.; Baulcombe, D.C. Requirement of sense transcription for homology-dependent virus resistance and trans-inactivation. Plant J. 1997, 12, 597-603. [CrossRef]

36. Van den Heuvel, J.F.J.M.; Boerma, T.M.; Peters, D. Transmission of potato leafroll virus from plants and artificial diets by Myzus persicae. Phytopathology 1991, 81, 150-154. [CrossRef]

37. Reutenauer, A.; Ziegler-Graff, V.; Lot, H.; Scheidecker, D.; Guilley, H.; Richards, K.; Jonard, G. Identification of beet western yellows luteovirus genes implicated in viral replication and particle morphogenesis. Virology 1993, 195, 692-699. [CrossRef] [PubMed]

38. Veidt, I.; Bouzoubaa, S.E.; Leiser, R.M.; Ziegler-Graff, V.; Guilley, H.; Richards, K.; Jonard, G. Synthesis of full-length transcripts of beet western yellows virus RNA: Messenger properties and biological activity in protoplasts. Virology 1992, 186, 192-200. [CrossRef]

39. Clark, M.F.; Adams, A.N. Characteristics of the microplate method of enzyme-linked immunosorbent assay for the detection of plant viruses. J. Gen. Virol. 1977, 34, 475-483. [CrossRef] [PubMed]

40. Laemmli, U.K. Cleavage of structural proteins during the assembly of the head of bacteriophage T4. Nature 1970, 227, 680-685. [CrossRef] [PubMed]

41. Revollon, S.; Strub, J.M.; Fitchette, A.C.; Wiss, L.; Gomord, V.; Van Dorsselaer, A.; Brault, V. A reinvestigation provides no evidence for sugar residues on structural proteins of poleroviruses and argues against a role for glycosylation of virus structural proteins in aphid transmission. Virology 2010, 402, 303-314. [CrossRef] [PubMed]

42. Hipper, C.; Monsion, B.; Bortolamiol-Becet, D.; Ziegler-Graff, V.; Brault, V. Formation of virions is strictly required for Turnip yellows virus long-distance movement in plants. J. Gen. Virol. 2014, 95, 496-505. [CrossRef] [PubMed]

43. Imlau, A.; Truernit, E.; Sauer, N. Cell-to-cell and long-distance trafficking of the green fluorescent protein in the phloem and symplastic unloading of the protein into sink tissues. Plant Cell 1999, 11, 309-322. [CrossRef] [PubMed]

44. Stadler, R.; Wright, K.M.; Lauterbach, C.; Amon, G.; Gahrtz, M.; Feuerstein, A.; Oparka, K.J.; Sauer, N. Expression of GFP-fusions in Arabidopsis companion cells reveals non-specific protein trafficking into sieve elements and identifies a novel post-phloem domain in roots. Plant J. 2005, 41, 319-331. [CrossRef] [PubMed]

45. Aguero, J.; Vives, M.C.; Velazquez, K.; Ruiz-Ruiz, S.; Juarez, J.; Navarro, L.; Moreno, P.; Guerri, J. Citrus leaf blotch virus invades meristematic regions in Nicotiana benthamiana and citrus. Mol. Plant Pathol. 2013, 14, 610-616. [CrossRef] [PubMed]

46. Candresse, T.; Le Gall, O.; Maisonneuve, B.; German-Retana, S.; Redondo, E. The use of green fluorescent protein-tagged recombinant viruses to test lettuce mosaic virus resistance in lettuce. Phytopathology 2002, 92, 169-176. [CrossRef] [PubMed]

47. Cruz, S.S.; Roberts, A.G.; Prior, D.A.; Chapman, S.; Oparka, K.J. Cell-to-cell and phloem-mediated transport of potato virus X. The role of virions. Plant Cell 1998, 10, 495-510. [CrossRef] [PubMed]

48. Lellis, A.D.; Kasschau, K.D.; Whitham, S.A.; Carrington, J.C. Loss-of-susceptibility mutants of Arabidopsis thaliana reveal an essential role for eIF(iso)4E during potyvirus infection. Curr. Biol. 2002, 12, 1046-1051. [CrossRef]

49. Matevz, R.; Florence, F.; Michel, T.; Ion, G.A.; Agnes, D.; Laurent, G.; Maja, K.; David, D.; Kristina, G.; Emmanuel, J.; et al. Fluorescently tagged potato virus Y: A versatile tool for functional analysis of plant-virus interactions. Mol. Plant Microbe Interact. 2015, 28, 739-750. [PubMed]

50. Naderpour, M.; Johansen, I.E. Visualization of resistance responses in Phaseolus vulgaris using reporter tagged clones of Bean common mosaic virus. Virus Res. 2011, 159, 1-8. [CrossRef] [PubMed]

51. Tatineni, S.; McMechan, A.J.; Bartels, M.; Hein, G.L.; Graybosch, R.A. In vitro transcripts of wild-type and fluorescent protein-tagged Triticum mosaic virus (family Potyviridae) are biologically active in wheat. Phytopathology 2015, 105, 1496-1505. [CrossRef] [PubMed] 
52. Krenz, B.; Bronikowski, A.; Lu, X.; Ziebell, H.; Thompson, J.R.; Perry, K.L. Visual monitoring of Cucumber mosaic virus infection in Nicotiana benthamiana following transmission by the aphid vector Myzus persicae. J. Gen. Virol. 2015, 96, 2904-2912. [CrossRef] [PubMed]

53. Bordat, A.; Houvenaghel, M.C.; German-Retana, S. Gibson assembly: An easy way to clone potyviral full-length infectious cDNA clones expressing an ectopic VPg. Virol. J. 2015, 12, 89. [CrossRef] [PubMed]

54. Cotton, S.; Grangeon, R.; Thivierge, K.; Mathieu, I.; Ide, C.; Wei, T.; Wang, A.; Laliberte, J.F. Turnip mosaic virus RNA replication complex vesicles are mobile, align with microfilaments, and are each derived from a single viral genome. J. Virol. 2009, 83, 10460-10471. [CrossRef] [PubMed]

55. Deng, P.; Wu, Z.; Wang, A. The multifunctional protein CI of potyviruses plays interlinked and distinct roles in viral genome replication and intercellular movement. Virol. J. 2015, 12, 141. [CrossRef] [PubMed]

56. Tilsner, J.; Linnik, O.; Wright, K.M.; Bell, K.; Roberts, A.G.; Lacomme, C.; Santa Cruz, S.; Oparka, K.J. The TGB1 movement protein of potato virus $\mathrm{X}$ reorganizes actin and endomembranes into the X-body, a viral replication factory. Plant Physiol. 2012, 158, 1359-1370. [CrossRef] [PubMed]

57. Ferriol, I.; Turina, M.; Zamora-Macorra, E.J.; Falk, B.W. RNA1-independent replication and GFP expression from Tomato marchitez virus isolate M cloned cDNA. Phytopathology 2016, 106, 500-509. [CrossRef] [PubMed]

58. Meng, B.; Venkataraman, S.; Li, C.; Wang, W.; Dayan-Glick, C.; Mawassi, M. Construction and biological activities of the first infectious cDNA clones of the genus Foveavirus. Virology 2013, 435, 453-462. [CrossRef] [PubMed]

59. Poque, S.; Pagny, G.; Ouibrahim, L.; Chague, A.; Eyquard, J.P.; Caballero, M.; Candresse, T.; Caranta, C.; Mariette, S.; Decroocq, V. Allelic variation at the rpv1 locus controls partial resistance to Plum pox virus infection in Arabidopsis thaliana. BMC Plant Biol. 2015, 15, 159. [CrossRef] [PubMed]

60. Verver, J.; Wellink, J.; Van Lent, J.; Gopinath, K.; Van Kammen, A. Studies on the movement of cowpea mosaic virus using the jellyfish green fluorescent protein. Virology 1998, 242, 22-27. [CrossRef] [PubMed]

61. Zheng, H.; Xiao, C.; Han, K.; Peng, J.; Lin, L.; Lu, Y.; Xie, L.; Wu, X.; Xu, P.; Li, G.; et al. Development of an agroinoculation system for full-length and GFP-tagged cDNA clones of cucumber green mottle mosaic virus. Arch. Virol. 2015, 160, 2867-2872. [CrossRef] [PubMed]

62. Cadena-Nava, R.D.; Comas-Garcia, M.; Garmann, R.F.; Rao, A.L.; Knobler, C.M.; Gelbart, W.M. Self-assembly of viral capsid protein and RNA molecules of different sizes: Requirement for a specific high protein/RNA mass ratio. J. Virol. 2012, 86, 3318-3326. [CrossRef] [PubMed]

63. Qu, F.; Morris, T.J. Encapsidation of turnip crinkle virus is defined by a specific packaging signal and RNA size. J. Virol. 1997, 71, 1428-1435. [PubMed]

64. Novoa, R.R.; Calderita, G.; Arranz, R.; Fontana, J.; Granzow, H.; Risco, C. Virus factories: Associations of cell organelles for viral replication and morphogenesis. Biol. Cell 2005, 97, 147-172. [CrossRef] [PubMed]

65. Haupt, S.; Stroganova, T.; Ryabov, E.; Kim, S.H.; Fraser, G.; Duncan, G.; Mayo, M.A.; Barker, H.; Taliansky, M. Nucleolar localization of potato leafroll virus capsid proteins. J. Gen. Virol. 2005, 86, 2891-2896. [CrossRef] [PubMed]

66. Tjallingii, W.F.; Hogen Esch, T. Fine structure of aphid stylet routes in plant tissues in correlation with EPG signals. Physiol. Entomol. 1993, 18, 317-328. [CrossRef]

(C) 2017 by the authors. Licensee MDPI, Basel, Switzerland. This article is an open access article distributed under the terms and conditions of the Creative Commons Attribution (CC BY) license (http://creativecommons.org/licenses/by/4.0/). 